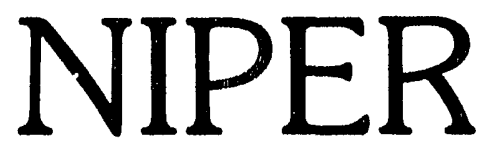

Commitment wiscellence

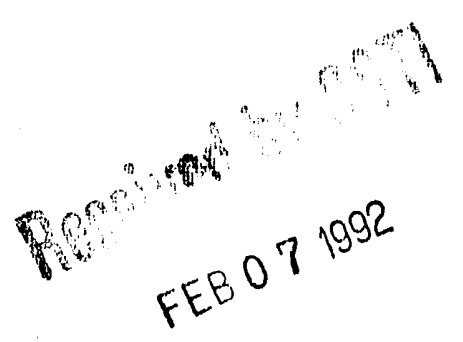

ANNUAL REPORT

\title{
SURFACTANT-ENHANCED ALKALINE FLOODING FIELD PROJECT
}

by

Troy R. French

Work Performed for the

U. S. Department of Enargy

Under Cooperative Agreement DE-FC22-83FE60149

National Institute for Petroleum and Energy Research IIT Research lnslilule P. O B Bx 2128 Barllesville, Oklahema 74005 01918 ) 336 2400 
NIPER-569

Distribution Category UC-122

October 1991

\title{
ANNUAL REPORT
}

\section{SURFACTANT-ENHANCED ALKALINE FLOODING FIELD PROJECT}

Project SGP41, Milestone 7, FY91

By

Troy R. French
NIPER- -569-Rev.

DE92 007487

Work Performed for the

U. S. Department of Energy

Under Cooperative Agreement DE-FC22-83FE60149

\author{
Thomas Reid, Project Manager \\ Bartlesville Project Office \\ U. S. Department of Energy
}

\begin{abstract}
DISCLAIMER
This report was prepared as an account of work sponsored by an agency of the United States Government. Neither the United States Government nor any agency thereof, nor any of their employees, makes any warranty, express or implied, or assumes any legal liability or responsibility for the accuracy, completeness, or usefulness of any information, apparatus, product, or process disclosed, or represents that its use would not infringe privately owned rights. Reference herein to any specific commercial produch, process, or service by trade name, trademark, manufacturer, or otherwise, does not necessarily constitute or imply its endorsement, recommendation, or favoring by the United States Government or any agency thereof. The views and opinions of authors expressed herein do not necessarily state or reflect those of the United States Government or any agency thereof.
\end{abstract}

IIT Research Institute National Institute for Petroleum and Energy Research Box 2128

Bartlesville, Oklahoma 74005

918 336-2400 


\section{TABLE OF CONTENTS}

Page

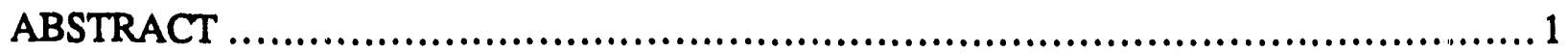

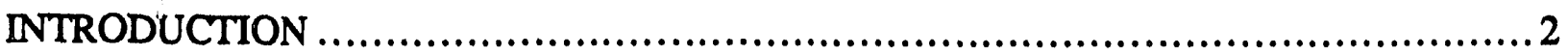

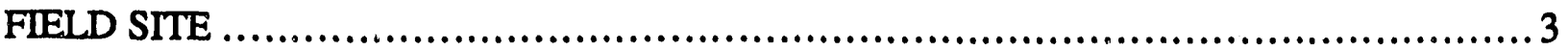

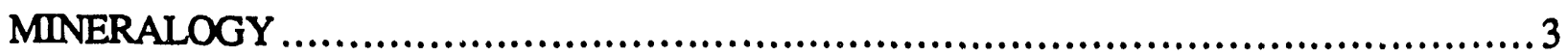

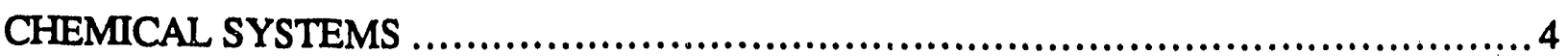

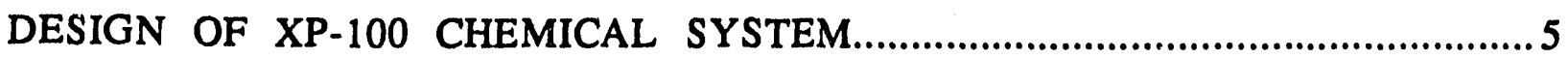

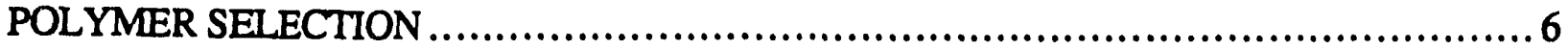

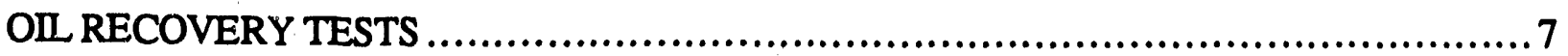

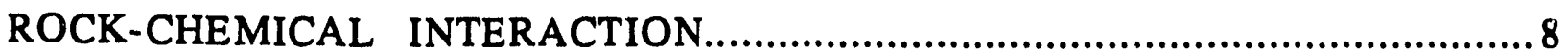

CONCLUSIONS AND RECOMMENDATIONS …................................... 9

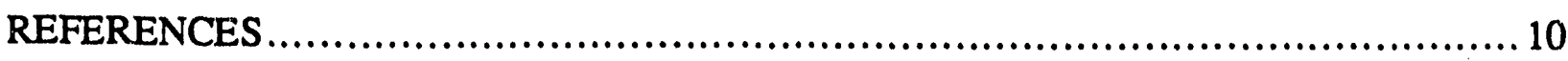

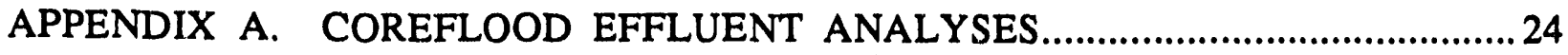

TABLES

1. Screening criteria for surfactant-enhanced alkaline flooding method..................... 12

2. Possible sites for surfactant-enhanced alkaline field project............................. 12

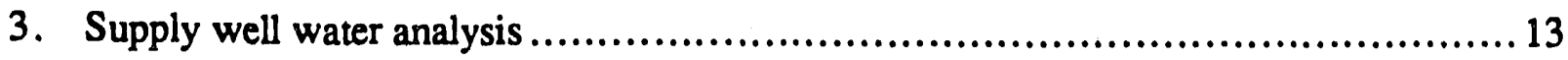

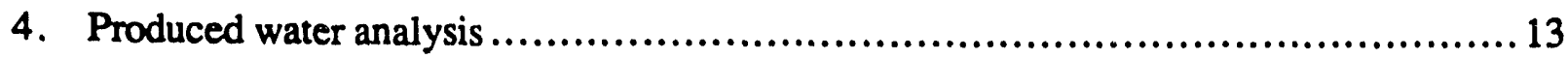

5. Chemical compatibility tests with supply well water ................................... 14

6. Chemical compatibility tests with produced water...................................... 14

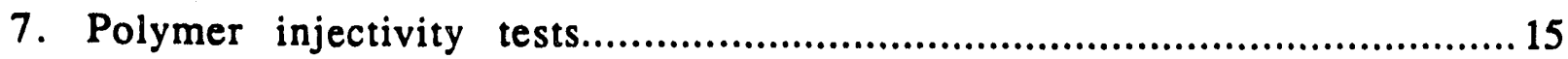

8. Summary of corefloods condusted with Hepler (KS) oil............................... 16

9. Alkali consumption with Hepler (KS) field core..............................................18

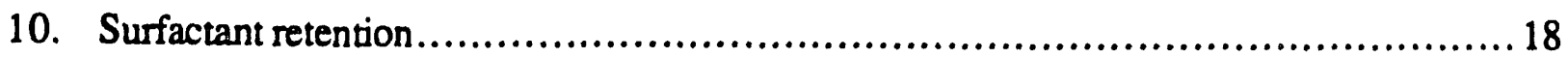

\section{ILLUSTRATIONS}

1. Interfacial tension between Hepler (KS) oil and optimized chemical formulations, $23^{\circ}$

2. Interfacial tension between Hepler (KS) oil and a mixture containing $0.5 \% \mathrm{~T}-33,0.45 \% \mathrm{STPP}$, and sodium bicarbonate in water from supply well, $23^{\circ} \mathrm{C}$.

3. Interfacial tension between Hepler (KS) oil and a mixture containing $0.5 \%$ XP-100, 2.0\% STPP, and Neodol $45-13$ in water from supply well, $23^{\circ} \mathrm{C}$ 


\section{ILLUSTRATIONS--Continued}

Page

4. Interfacial tension between Hepler (KS) oil and a mixture containing $0.5 \%$ XP-100, $0.45 \%$ STPP, and sodium bicarbonate in water from

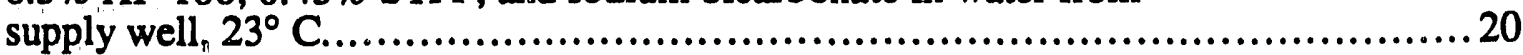

5. Pfizer Flopaam 3230E polymer injectivity test.................................. 21

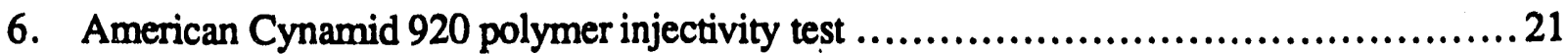

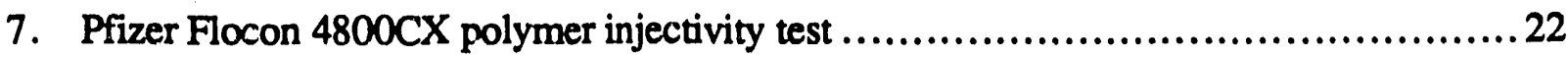

8. Viscosity of Flopaam $3230 \mathrm{~S}$ polymer in supply well water, $11.5 \mathrm{sec}^{-1}, 23^{\circ} \mathrm{C} \ldots \ldots \ldots \ldots .22$

9. Effect of polymer concentration on tertiary oil recovery..............................2 23

A1. Coreflood RP-2 oil saturation and effluent oil cut................................... 24

A2. Coreflood RP-2 effluent viscosity and surfactant analysis ............................2 24

A3. Coreflood RP-2 effluent alkalinity and surfactant analysis.............................25

A4. Coreflood RP-3 oil saturation and effluent oil cut ................................. 25

A5. Coreflood RP-8 oil saturation and effluent oil cut...................................26

A6. Coreflood RP-16 oil saturation and effluent oil cut..............................................26

A7. Coreflood RP-16 effluent viscosity and surfactant analysis............................2 27

A8. Coreflood RP-18 oil saturation and effluent oil cut..............................................2

A9. Coreflood RP-18 effluent viscosity and surfactant analysis...........................28

A10. Coreflood RP-19 oil saturation and effluent oil cut................................................28

A11. Coreflood RP-19 effluent viscosity and surfactant analysis............................29

A12. Coreflood RP-20 oil saturation and effluent oil cut.............................................29 


\title{
SURFACTANT-ENHANCED ALKALINE FLOODING FIELD PROJECT
}

\author{
by Troy R. French
}

\begin{abstract}
The Tucker sand of Hepler (KS) field is a candidate for surfactant-enhanced alkaline flooding. The geology of the Hepler site is typical of many DOE Class I reservoirs. The Tucker sand of Hepler field was deposited in a fluvial dominated deltaic environment. Hepler oil can be mobilized with either chemical system 2 or chemical system 3, as described in this report. Oil fields in the Gulf Coast region are also good candidates for surfactant-enhanced alkaline flooding.

The results from laboratory tests conducted in Berea sandstone cores with oil and brine from Helper (KS) field are encouraging. The crude oil is viscous and non-acidic and, yet, was mobilized by the chemical formulations described in this report. Significant amounts of the oil were mobilized under simulated reservoir conditions. The results in Berea sandstone cores were encouraging and should be verified by tests with field core. Consumption of alkali, measured with field core, was very low. Surfactant loss appeared to be acceptable.

Despite the good potential for mobilization of Hepler oil, certain reservoir characteristics such as low permeability, compartmentalization, and shallow depth place constraints on applications of any chemical system in the Tucker sand. These constraints are typical of many DOE Class I reservoirs.
\end{abstract}

The most promising injection strategy for the Tucker sand of Hepler field appears to be as follows:

(1) $0.10 \mathrm{PV}$ sodium bicarbonate + STPP (sodium tripolyphosphate) preflush in supply water.

(2) 0.20 PV surfactant-enhanced alkaline formulation that contains STPP + sodium bicarbonate + Chaser XP-100 surfactant + polyacrylamide polymer in supply water (chemical system 3 in this report).

(3) $0.15 \mathrm{PV}$ graded concentration of polyacrylamide polymer in supply water. 
Although Hepler field is not a perfect reservoir in which to apply surfactant-enhanced alkaline flooding, Hepler oil is particularly amenable to mobilization by surfactant-enhanced alkaline systems. A field test is recommended, dependent upon final evaluation of well logs and cores from the proposed pilot area.

\section{INTRODUCTION}

Under the sponsorship of the U. S. Department of Energy (DOE), IIT Research Institute/National Institute for Petroleum and Energy Research (NIPER) and Kerr-McGee Chemical Corporation, research has led to the development of a novel surfactant-enhanced alkaline flooding process. NIPER is beginning a DOE-industry sponsored alkaline flooding field pilot test using this patented surfactant-enhanced alkaline process, ${ }^{1}$ The objectives of the project are to demonstrate the feasibility of the technology by conducting a field pilot test. This near-term application of a promising EOR technology in a fluvial-dominated deltaic reservoir, which has been given the highest priority by DOE, is consistent with DOE's National Energy Strategy Advanced Oil Recovery Initiative. ${ }^{2}$

The benefits from performing the field test will include: (1) acquisition of information and data that will help to demonstrate the applicability of surfactant-enhanced alkaline flooding as a cost-effective EOR method, (2) transfer of this surfactant-enhanced alkaline flooding technology to the petroleum industry, and (3) development of procedures for designing and applying this technology that will assist independent producers in sustaining production from mature producing oil fields rather than abandoning marginal wells.

The scope of work for this reporting period included selection of a field site for the pilot, characterization of the target reservoir, and design of an alkaline formulation. After tentative selection of the site, laboratory tests were conducted to design and optimize the alkaline flooding formulation. Samples of crude oil, brine, and reservoir rock from wells in the pilot area were obtained from the operator. Samples of suitable surfactants available in commercial-scale quantities were obtained from surfactant nanufacturers. Several commercially available surfactants were tested to optimize the cost of the chemical injectant. Laboratory work included phase behavior, chemical compatibility, interfacial tension, alkali consumption, and oil production tests. This report is an annual report that covers site selection and design of the surfactant-alkaline system. This work was performed in FY91. 


\section{FIELD SITE}

There are constraints to applications of weak alkalis for chemical flooding. These constraints have been identified and are included in table 1 which is a list of reservoir screening criteria developed by NIPER. ${ }^{3}$

Candidate reservoirs for surfactant-enhanced alkaline flooding are, however, difficult to identify because of the scarcity of data on mineralogy and alkali consumption capacity. Several oil fields were identified as candidates for low-pH alkaline flooding by (1) examination of data bases and (2) contact with oil producers who have the motivation to perform cost-effective EOR.

The site selected for the field test is in Hepler (KS) oil field. Hepler field is located in Crawford and Bourbon counties, KS. The field was discovered in 1917. Since 1948, recorded production totals 969,761 bbl oil. 4 In 1980, 85 wells were counted. 5 The 1988 production was $19,731 \mathrm{bbl}$ for 52 active wells and net pay thickness was reported to vary from 10 to $29 \mathrm{ft}$ net pay.

Several alternative sites with favorable reservoir characteristics were identified in the Gulf Coast area. Reservoir properties for the Hepler and alternative sites are listed in table 2. The alternatives have high-permeability sands and low salinities and were selected as a result of a database search. Should unexpected problems be encountered at the Hepler site, the most likely alternative is Government Wells, North (TX) field. A few experiments have been conducted with oil and brine from Government Wells, North.

The geology of the Hepler site is typical of many Class I reservoirs. ${ }^{6-7}$ The Tucker sand (Bartlesville sand) of Hepler field is a Class I reservoir that was deposited in a fluvial dominated deltaic environment. Factors to be considered are the effects of low permeability and depositional compartmentalization in the Tucker sand of Hepler field. Estimated high oil saturations, because this area of Hepler field has not been produced, makes this area an especially attractive target for the operator of the field pilot site. Another important factor is that the pressure generated due to injection of EOR chemicals must not exceed fracture pressure. This is a real constraint in shallow sites like Hepler that contain high-viscosity oils.

\section{MINERALOGY}

A sample of field core from the Hepler site was analyzed for mineral content with X-ray diffraction. The analysis was encouraging because the clay content was low. Kaolinite, the clay most detrimental to alkaline flooding, was present at the $3 \%$ level, which is acceptable. ${ }^{3}$ Montmorillonite, which has high ion exchange capacity, is not present in the Tucker sand. 


\section{CHEMICAL SYSTEMS}

Four of several chemical systems that have been studied specifically for recovery of Hepler crude are described in this report. Each of these chemical systems was optimized to provide the lowest possible interfacial tension (IFT) with Hepler oil. The IFT between three of these four systems and Hepler oil is shown in figure 1. The optimization procedures and results with two of these systems have previously been discussed in detail. ${ }^{8}$ These two systems will be discussed briefly in this report. Both of these chemical systems contained Petrostep B series surfactants, a mixture of sodium bicarbonate and sodium carbonate ( $\mathrm{pH} 9.5$ ), and $\mathrm{NaCl}$ in deionized water (DIW).

The interfacial tension (IFT) between Hepler oil and an optimized pH 9.5 chemical system that contained $0.2 \%$ Petrostep B-120 surfactant, $0.095 \mathrm{~N} \mathrm{NaHCO}_{3}, 0.095 \mathrm{~N} \mathrm{Na}_{2} \mathrm{CO}_{3}$, and $1 \%$ $\mathrm{NaCl}$ (chemical system 1) is shown in figure 1. The minimum IFT achieved was $97 \mu \mathrm{N} / \mathrm{m}$, which is not especially favorable for mobilization of residual oil at normal frontal advance rates. Values below $10 \mu \mathrm{N} / \mathrm{m}$ have been shown to be favorable for the mobilization of significant amounts of residual oil. 9 A coreflood with this chemical system did not significantly reduce residual oil saturation, and it was decided not to perform additional work with this system.

The dynamic IFT between Hepler oil and an optimized chemical system composed of $0.25 \%$ Petrostep B-110 surfactant, 0.15\% Petrostep B-105 surfactant, 0.095N $\mathrm{NaHCO}_{3}, 0.095 \mathrm{~N}$ $\mathrm{Na}_{2} \mathrm{CO}_{3}$, and $1 \% \mathrm{NaCl}$ in DIW (chemical system 2) is also shown in figure 1. The minimum IFT achieved was about $6 \mu \mathrm{N} / \mathrm{m}$, which is favorable to mobilization of residual oil.

Corefloods were performed with the second chemical system described above. This chemical system was composed of $0.15 \%$ Petrostep B-105 surfactant $+0.25 \%$ Petrostep B-110 surfactant, $0.095 \mathrm{~N} \mathrm{NaHCO}_{3}$, and $0.095 \mathrm{~N} \mathrm{Na}_{2} \mathrm{CO}_{3}$ in $1 \% \mathrm{NaCl}$. Sec-butyl alcohol (2-butanol) was added to the chemical formulation to improve the phase behavior of the solution. The addition of $2 \%$ alcohol resulted in a chemical solution that was less turbid. All of these corefloods were performed in Berea sandstone, except one coreflood which was performed in Bartlesville sandstone. Sufficient Hepler field core was not available to perform the floods in Tucker sandstone. The Tucker sandstone and Bartlesville sandstone are both Cherokee group sands. However, very favorable oil recovery results were obtained with the second chemical system tested (0.15\% Petrostep B-105 surfactant $+0.25 \%$ Petrostep B-110 surfactant, $0.095 \mathrm{~N} \mathrm{NaHCO}_{3}$, and $0.095 \mathrm{~N} \mathrm{Na}_{2} \mathrm{CO}_{3}$ in $1 \% \mathrm{NaCl}$ ) when Berea cores saturated with Hepler oil were used. Oil recoveries as high as $94 \%$ OOIP (waterflood and chemical flood) were achieved when large volumes $(0.75 \mathrm{PV})$ of chemicals were injected. 8 
The IFT data for a third optimized chemical system (chemical system 3 ) are also shown in figure 1 . This chemical system contains $0.5 \%$ Chaser XP-100 surfactant, $0.45 \%$ sodium tripolyphosphate (STPP), and sodium bicarbonate (chemical system 3). The IFT behavior is shown for $1.2 \%$ and $1.6 \%$ sodium bicarbonate concentrations. The Chaser XP-100 chemical systems were formulated in water from a water supply well located in Hepler field. The chemical analysis of this water is shown in table 3. Since water from the supply well will be used for the field project, the results obtained with the optimized chemical system that contains XP-100 in supply water are the focus of this report. However, some pertinent results obtained with the chemical system that contains $0.15 \%$ Petrostep B-105 surfactant $+0.25 \%$ Petrostep B-110 surfactant, $0.095 \mathrm{~N} \mathrm{NaHCO}_{3}$, and $0.095 \mathrm{~N} \mathrm{Na}_{2} \mathrm{CO}_{3}$ in $1 \% \mathrm{NaCl}$ are also discussed.

Another chemical system (chemical system 4) was also tested. This chemical system contained Igepon T-33, which is a less expensive surfactant. The results from IFT measurements are shown in figure 2. No IFT values were measured below $300 \mu \mathrm{N} / \mathrm{m}$; therefore, these systems would not be expected to mobilize significant amounts of Hepler oil, and no coreflood tests were performed with chemical system 4 .

\section{DESIGN OF XP-100 CHEMICAL SYSTEM}

As previously mentioned, the Tucker sand of Hepler field is a Class I, fluvial dominated deltaic reservoir. A chemical formulation (chemical system 3, described above) was developed for use in Hepler field. ${ }^{8}$ After discussions with the field operator, this chemical formulation was designed for make-up with Mississippian supply water. The water produced from the supply well has a lower salinity and higher divalent ion level than was originally used for designing the chemical formulation. Water from the supply well has a pH value of 7.9 and contains $2,500 \mathrm{ppm}$ TDS. Connate water is $\mathrm{pH} 7.3$ and has a higher salinity value than water from the supply well. Return water (from waterflooding) contains $10,800 \mathrm{ppm}$ TDS. (See table 4.) The redesigned chemical formulation eliminates potential problems that could occur when mixing the chemicals in water from the supply water well and minimizes (but does not completely eliminate) precipitation that will occur within the reservoir.

A summary of tests to determine the compatibility of chemicals with supply water is given in table 5. $\mathrm{Na}_{2} \mathrm{CO}_{3}$ and, to a much lesser extent, $\mathrm{NaHCO}_{3}$ caused precipitation with supply water. STPP (sodium tripolyphosphate), STPP $+\mathrm{NaHCO}_{3}$, and STPP $+\mathrm{Na}_{2} \mathrm{CO}_{3}$ dissolved in supply water without precipitation. The composition of produced brine (return water from waterflooding) from Hepler field is given in table 4. Since reservoir brine contains higher salinity and more divalent ions than supply water, the compatibiliy of the chemical formulation with reservoir brine is 
of interest. A summary of tests performed with reservoir brine (return water) is given in table 6 . All mixtures of STPP, $\mathrm{NaHCO}_{3}$, and $\mathrm{Na}_{2} \mathrm{CO}_{3}$ caused precipitation with return water. A mixture of STPP $+\mathrm{NaHCO}_{3}$ was selected as most promising because it eliminates precipitation problems when mixing in supply water and minimizes precipitation that will occur on dilution with connate water.

A series of IFT measurements was conducted with Chaser XP-100 and several cosurfactants. The co-surfactants tested were Neodol 45-13, an ethoxylated alcohol, Igepal CO-730, an ethoxylated alcohol, and Steposol CA-207, an anionic co-surfactant. The IFT results shown in figure 3 are typical of the IYT behavior exhibited by mixtures of Chaser XP-100 and cosurfactants. Addition of co-surfactant caused IFT to increase.

The most promising chemical system, shown in figures 1 and 4 , was composed of $0.5 \%$ Chaser XP-100, 0.45\% STPP, and 1.2\% $\mathrm{NaHCO}_{3}$. Also promising was the same XP-100/STPP mixture with $1.6 \% \mathrm{NaHCO}_{3}$. The mixture containing $1.2 \% \mathrm{NaHCO}_{3}$ had an initial IFT value of $66.5 \mu \mathrm{N} / \mathrm{m}$ and an equilibrium value of $0.4 \mu \mathrm{N} / \mathrm{m}$. The mixture containing $1.6 \% \mathrm{NaHCO}_{3}$ had an initial IFT of $20.3 \mu \mathrm{N} / \mathrm{m}$ and an equilibrium value of $13.8 \mu \mathrm{N} / \mathrm{m}$.

Phase behavior tests were conducted with Hepler oil and the above described mixtures of Chaser XP-100, STPP, and several concentrations of $\mathrm{NaHCO}_{3}$. When $\mathrm{NaHCO}_{3}$ concentration was increased in increments from 0.8 to $2.4 \%$, the most significant observation was that the emulsions that were produced separated more easily in the 1.2 to $1.6 \% \mathrm{NaHCO}_{3}$ concentration range. The chemical systems that contain $0.5 \%$ Chaser XP-100, 0.45\% STPP and $1.2-1.6 \%$ $\mathrm{NaHCO}_{3}$ were selected for oil recovery (coreflood) measurements.

\section{POLYMER SELECTION}

Due to the viscous nature of Hepler oil, polymier should be added to the chemical formulation to achieve better mobility control. The pressure generated due to injection of EOR chemicals must not exceed fracture pressure. This is a major constraint in shallow sites like Hepler field. For these reasons, polymers used for mobility control during surfactant-alkaline flooding must be selected carefully. Because of the relatively low permeability range of the Hepler pay zone (Tucker sand) and the apparent problem of propagating polymer in tight porous media, a biopolymer or low-molecular-weight polyacrylamide polymer is recommended. 
There are a large number of commercially available polymers, and several polymers were selected for injection tests. (See table 7.) Three polyacrylamides and one biopolymer were tested for injectability in tight Berea cores. The polyacrylamide polymer manufacturers did not furnish exact molecular weights, but the molecular weight of one of the polyacrylamides was about $7 \times 10^{6}$ Daltons; the other two polyacrylamides had molecular weights equal to or lower than $5 \times 10^{6}$ Daltons. The brines used for the injection tests were deionized water, $1 \% \mathrm{NaCl}$, and $1.2 \%$ TDS brine with divalent ions. The permeabilities of the Berea cores were from 25 to $101 \mathrm{mD}$.

The results of three of the injectivity tests are shown in figures 5 through 7. All four polymers wers injectable through the tight cores. The only exception was when deionized water was used as the aqueous fluid. Polyacrylamide polymer viscosity was higher at this "no salt" condition, and the polymer molecules would not pass through the tight porous media. Pfizer Flocon 4800CX biopolymer, a relatively expensive polymer, and Pfizer Flopaam 3230E polyacrylamide polymer were selected for mobility control in coreflood oil recovery tests.

The concentrations of Pfizer Flopaam 3230S low-molecular-weight polyacrylamide polymer for field use with the above described chemical formulation were determined. The viscosities of Flopaam 3230S in chemical system 3 and in supply water are shown in figure 8. In the above described chemical system, $1250 \mathrm{ppm}$ of polymer provided a viscosity of about $9 \mathrm{cP}$ at $11.5 \mathrm{sec}^{-1}$, which is probably the maximum that can be satisfactorily injected in Hepler field. A mixture containing $750 \mathrm{ppm}$ of the same polymer in supply water (without other added chemicals) has a viscosity of $9 \mathrm{cP}$, which can be graded to a lower concentration during polymer postflush. Since Hepler oil is viscous, the effect of polymer concentration on oil recovery was studied, but the practical limits on polymer viscosity are in the range stated above.

\section{OIL RECOVERY TESTS}

An important parameter related to mobility control is oil viscosity. In situ oil viscosity of Hepler oil is near $76 \mathrm{cP}$; therefore, a high concentration of polymer will be needed to achieve a favorable mobility ratio. Because of the shallow depth $(575 \mathrm{ft})$ of the reservoir, the concentration of biopolymer that can be injected at reasonable frontal advance rates will be limited to about 1,000 ppm. Results of corefloods are summarized in table 8. Analyses of coreflood effluents are shown in appendix A. In figure 9, the oil recoveries are compared at two polymer concentrations. Corefloods RP-2 and RP-3, listed in table 3, were performed with chemical system 2 and 3,500 ppm biopolymer concentration. Coreflood RP-8 was performed with the same chemical system and $1,000 \mathrm{ppm}$ of biopolymer. The amount of oil mobilized was reduced from $84.1 \%$ of the oil 
that remained after waterflood to $51.5 \%$ when the polymer concentration was reduced from 3,500 to $1,000 \mathrm{ppm}$. This result was expected. Mobility ratio was not calculated because the endpoint relative permeability of polymer, $K_{r d}^{\prime}$, has not been measured; however, useful information is gained from the viscosity ratio, $R=\mu_{\mathrm{o}} / \mu_{\mathrm{d}}$, where $\mu_{0}$ is the viscosity of the oil and $\mu_{\mathrm{d}}$ is the viscosity of the displacing phase. The value of $R$ for 3,500-ppm polymer is 0.8 ; the value for $1,000-\mathrm{ppm}$ is 5.1. For values of $\mathrm{R}<10$, a stable and favorable type of displacement is expected. 10

Therefore, even with reduced polymer concentration, the amount of oil mobilized appears to be significant enough to justify field injection. This is significant because the most expensive chemical component of the system is polymer, and polymer concentration is limited by reservoir characteristics.

The effect of reducing the size of the injected slugs is shown by comparison of corefloods RP-16 and RP-18 (chemical system 3). (See table 8 and appendix A.) Both cores have high permeability. Total volumes of injected chemicals were, respectively, 2.0 and $0.45 \mathrm{PV}$. When the size of the injected volumes was decreased, oil recovery was reduced from 51.5 to $27.5 \%$ of the oil that remained after waterflooding.

Comparison of corefloods RP-18 and RP-19 shows the effect of permeability when small slug sizes of chemicals were used. The permeability of cores RP-18 and RP-19 were, respectively, 1359 and $96 \mathrm{mD}$. The effect of permeability reduction was to reduce the an suunt of residual oil recovered from 27.5 to $22.8 \%$.

The effect of beginning the chemical flood at initial oil saturation (no waterflood) was simulated in coreflood RP-20. Total oil recovery was only slightly reduced when compared to coreflood RP-19, which was waterflooded.

\section{ROCK-CHEMICAL INTERACTION}

A sample of field core from the Hepler site was analyzed for mineral content with X-ray diffraction. The analysis was encouraging because the clay content was low. Kaolinite, the clay most detrimental to alkaline flooding, was present at the $3 \%$ level, which is acceptable. ${ }^{3}$ Montmorillonite, which has high ion exchange capacity, was not found in the Tucker sand. Total clay content was less than $10 \%$. 
The consumption for several alkalis by crushed Hepler core is given in table 9 . The samples were prepared at 1:1 solid/liquid ratios and placed in a shaker at reservoir temperature for 3 days (short-term). A separate set of samples was aged for 31 days (long-term). The fact that $\mathrm{Na}_{2} \mathrm{CO}_{3}$ and $\mathrm{NaOH}$ were equally consumed indicates that these short-term reactions may be due to ion exchange reactions. The long-term consumption of carbonates was much less than for sodium hydroxide. All of the consumption measurements indicate very low consumption of alkali by Hepler core. These results are also in agreement with other results that indicate greatly reduced alkali consumption when the $\mathrm{pH}$ is below 11.11-13 The consumption of carbonates is low enough that in-depth penetration of the reservoir should result before the alkali is consumed by rock-alkali reactions.

The adsorption of surfactant was also measured. Scarcely any of the surfactant was lost due to partitioning into the crude oil; however, significant losses by adsorption onto Hepler reservoir rock were measured in static (bottle) tests conducted at ambient temperature $\left(23^{\circ} \mathrm{C}\right)$, which is very close to reservoir temperature. Results are given in table 10. Static adsorption is often 10 times higher than dynamic adsorption. Table 10 also gives dynamic measurements, which are much lower. The dynamic measurements were made with corefloods conducted in Berea sandstone and are, therefore, only an indication of the amount of dynamic adsorption that may occur in Hepler core. It is encouraging that the amount of surfactant adsorbed decreased as surfactant slug size was decreased. When core plugs are available from Hepler field, dynamic measurements will be made during corefloocls conducted with Hepler core. Based on dynamic results measured for chemical system 3 in Berea core, it is expected that surfactant loss in Hepler core will not be excessively high.

\section{CONCLUSIONS AND RECOMMENDATIONS}

1. The Tucker sand of Hepler field is a candidate for surfactant-enhanced alkaline flooding. There are also other good candidates in the Gulf Coast region.

2. Hepler oil can be mobilized in Berea sandstone core with either chemical system 2 or chemical system 3, as clescribed in this report.

3. Despite the good potential for mobilization of Hepler oil, certain reservoir characteristics such as low permeability, compartmentalization, and shallow depth place constraints on applications of any chemical system. in the Tucker sand. These constraints are typical of those of many DOE Class I reservoirs. 
4. The most promising injection strategy appears to be as follows:

(1) 0.10 PV sodium bicarbonate + STPP (sodium tripolyphosphate) preflush in supply water. 14

(2) 0.20 PV surfactant-enhanced alkaline formulation that contains STPP + sodium bicarbonate + Chaser XP-100 surfactant + polyacrylamide polymer in supply water (chemical system 3 in this report).

(3) $0.15 \mathrm{PV}$ graded concentration of polyacrylamide polymer in supply water.

Although Hepler field is not a perfect reservoir in which to apply surfactant-enhanced alkaline flooding, Hepler oil is particularly amenable to mobilization by surfactant-enhanced alkaline systems, and it is recomm .ıded, at this time, to initiate a field project, dependent on final evaluation of well logs and cores from the proposed pilot area.

\section{REFERENCES}

1. Peru, D.A. Aqueous Flooding Methods for Tertiary Oil Recovery. U. S. Patent 4,817,715, April 1989.

2. U.S. Department of Energy. Oil Research Program Implementation Plan. Dept. of Znergy Report No. DOE/FE-0188P, April 1990.

3. Lorerz, P. B. and D. A. Peru. Selection of Reservoirs for Surfactant-Enhanced Alkaline Flocding Using Sodium Bicarbonate. Oil and Gas J., v. 87, No. 47, September 1989, pp. 53-55.

4. Oil and Gas Production in Kansas, Kansas Geological Survey, 1988.

5. Paul, E. and E. L. Bahnmaier. Enhanced Oil Recovery Operations in Kansas-1980. Energy Resources Series 19, Kansas Geological Survey, 1981.

6. Bradshaw, D. T. Geologic Variables Influencing Production in the Eastburn Field, Vernon County, Missouri. M.S. Thesis, Colorado State University, Fort Collins, Colorado, 1985.

7. Tomes, J. T. Environmental and Diagenetic History of the Upper Warner Sandstone, Southwest Vernon County, Missouri. M.S. Thesis, Colorado State University, Fort Collins, Colorado, 1986.

8. French, Troy R. Design of Chemical Formulation for Project SGP41. U. S. Dept. of Energy Report No. NIPER-530, May 1991.

9. French, T.R., D.A. Peru, and S.D. Thomton. Low pH Alkaline Chemical Formulations. U. S. Dept. of Energy Report No. NIPER-375, October 1988.

10. Dake, L. P. Fundamentals of Reservoir Engineering. Elsevier Scientific Publishing Co., New York, 1978. pp. 368-69.

11. Cheng, K. H. Chemical Consumption During Alkaline Flooding: A Comparative Evaluation. Pres. at the Fifth Joint SPE/DOE Symposium on Enhanced Oil Recovery, Tulsa, OK, April 20-23, 1986, SPE/DOE paper 14944. 
12. French, T.R. and T.E. Burchfield. Design and Optimization of Alkaline Flooding Formulations. Pres. at the Seventh Joint SPE/DOE Symposium on Enhanced Oil Recovery, Tulsa, OK, April 1990, SPE/DOE paper 20238.

13. Burk, J. H. Comparison of Sodium Carbonate, Sodium Hydroxide, and Sodium Orthosilicate for EOR. SPE Reservoir Eng., v. 2, No. 1, February 1987, pp. 9-16.

14. French, T. R. and C. B. Josephson. Alkaline Flooding Injection Strategy. Dept. of Energy Repon No. NIPER-563, to be published. 
TABLE 1. - Screening criteria for surfactant-enhanced alkaline flooding method

- Crude oil viscosity less than $100 \mathrm{cP}$

- Permeability greater than $10 \mathrm{mD}$

- Brine salinity less than 200,000 TDS

- Temperature less than $200^{\circ} \mathrm{F}$ and depth less than $9,000 \mathrm{ft}$

- Formation type - sandstone or limestone

- Acid number greater than $0.3 \mathrm{mg}$ of $\mathrm{KOH}$ per $\mathrm{g}$ of crude oil is desirable but not essential

- Clay content should be moderate, but is dependent upon clay type

- No gypsum (less than $0.1 \%$ ), or alternately less than 1,000 ppm sulfate in the brine

- Divalent ion exchange capacity less than $5 \mathrm{meg} / \mathrm{kg}$, or altemately less than $1 \%$ montmorillonite and less than 0.005 equivalent fraction of divalent ions in the brine

- In situ $\mathrm{pH}$ greater than 6.5 , or alternately less than 0.01 mole fraction of $\mathrm{CO}_{2}$ in the produced gas

TABLE 2. - Possible sites for surfactant-enhanced alkaline field project

\section{Eield}

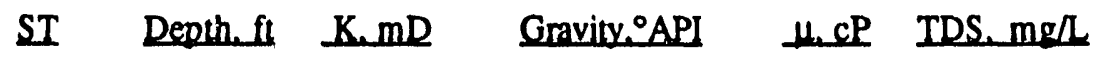

Heplex

KS $\quad 575$

80

26.1

$76 \quad 11,900$

Gov't Wells N.

TX

2,200

800

20.1

$2 \quad 5,680$

Lomia Novia

TX

2,750

600

26.0

$40 \quad 13,000$

Ganado West

TX

4,730

1,411

24.4

$4 \quad 25,000$

Colletuo Creek

TX $\quad 2,776$

500

21.0

$6 \quad 27,000$


TABLE 3. - Supply well water analysis $\mathrm{pH}=7.9$

\begin{tabular}{lcc}
\hline \multicolumn{1}{c}{ Radical } & Concentration, mg/L & Percent \\
\hline Sodium \& Potassium & 830. & 33.43 \\
Iron & 0.05 & - \\
Barium & 1.0 & 0.04 \\
Calcium & 12. & 0.48 \\
Magnesium & 9.4 & 0.38 \\
Chlorides & 908. & 36.56 \\
Carbonates & & \\
Bicarbonates & 720. & 28.99 \\
Sulphates & 3.0 & 0.12 \\
TOTAL SOLIDS & 2.483. & 100.00 \\
\hline
\end{tabular}

TABLE 4. - Produced water analysis $\mathrm{pH}=7.3$

\begin{tabular}{lcc}
\hline \multicolumn{1}{c}{ Radical } & Concentration, mg/L & Pencent \\
\hline Sodium \& Potassium & $3,756$. & 34.65 \\
Iron & 0.06 & - \\
Barium & 95. & 0.88 \\
Calcium & 136. & 1.25 \\
Magnesium & 79. & 0.73 \\
Chloricies & 5.674. & 52.35 \\
Carbonates & & \\
Bicarbnnates & $1,098$. & 10.13 \\
Sulphates & 1.0 & 0.01 \\
TOT, STL SOLIDS & $10,839$. & 100.00 \\
\hline
\end{tabular}


TABLE 5. - Chemical compatibility tests with supply well water

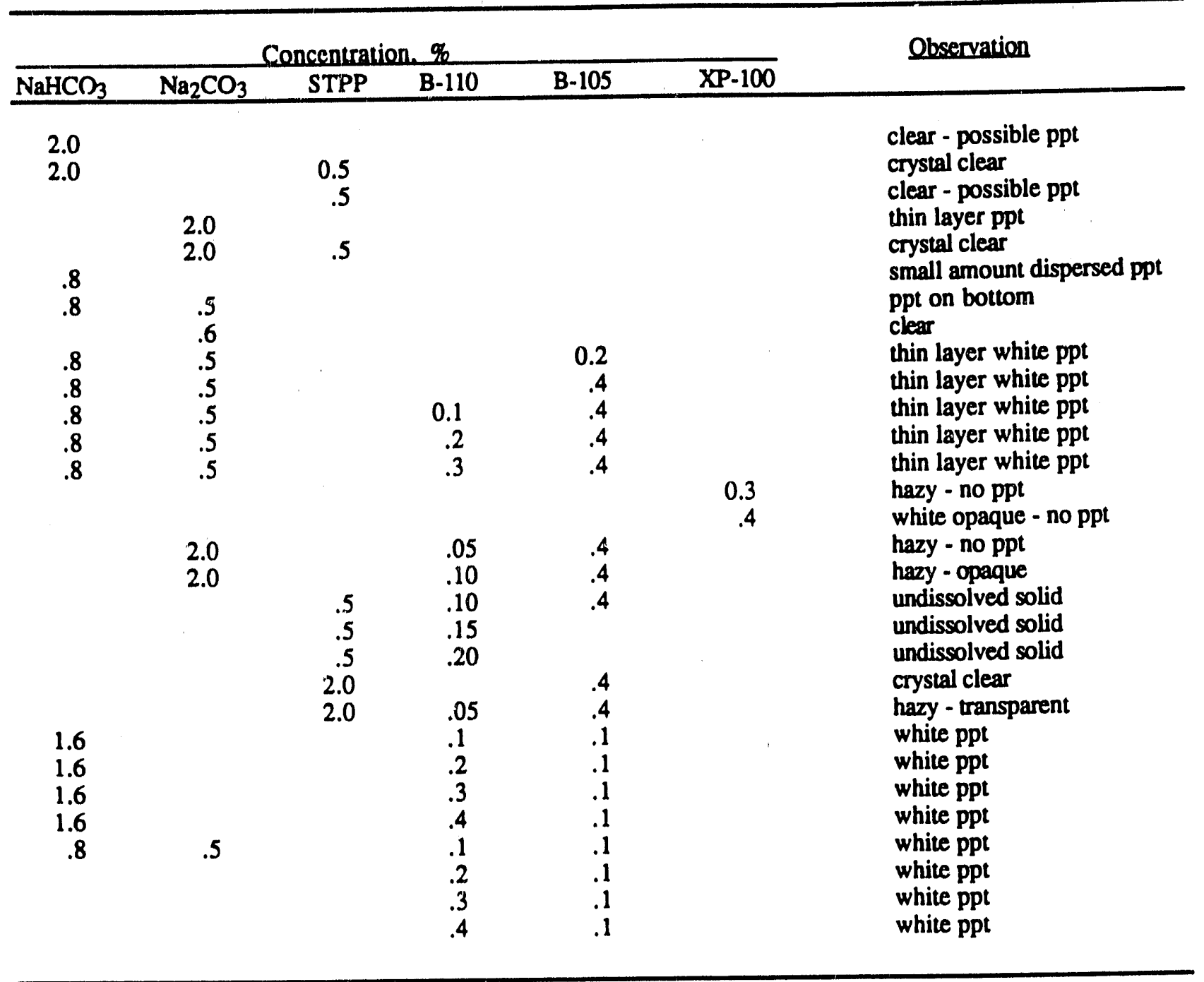

TABLE 6. - Chemical compatibility tests with produced water

\begin{tabular}{lll}
\multicolumn{3}{c}{ Concentration. $\%$} \\
$\mathrm{NaHCO}_{3} \quad \mathrm{Na}_{2} \mathrm{CO}_{3} \quad$ STPP
\end{tabular}

2.0

2.0

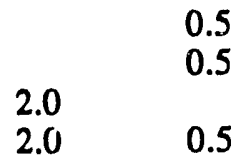

\section{Observations}

thin layer white ppt

flocculent white ppt

slight amount suspended ppt

$1 / 8^{\prime \prime}$ white ppt

$1 / 16^{\text {" white }} \mathrm{ppt}$ 
TABLE 7. - Polymer injectivity tests

\begin{tabular}{lccc}
\hline Polymer & $\begin{array}{c}\text { Molecular weight, } \\
\text { Daltons }\end{array}$ & $\begin{array}{c}\text { Core permeability, } \\
\mathrm{mD}\end{array}$ & Brine \\
\hline $\begin{array}{l}\text { Pfizer Flocon } \\
4800 \mathrm{CX}\end{array}$ & & 80 & $\begin{array}{l}1200 \mathrm{ppm} \mathrm{TDS} \\
(960 \mathrm{ppm} \mathrm{Ca}+ \\
\left.390 \mathrm{ppm} \mathrm{Mg}^{++}\right)\end{array}$ \\
$\begin{array}{l}\text { American Cynamid } \\
\text { No. } 920\end{array}$ & $5 \times 10^{6}$ & & $1 \% \mathrm{NaCl}$ \\
$\begin{array}{l}\text { Pfizer Flopaam } \\
3230 \mathrm{E}\end{array}$ & $7-8 \times 10^{6}$ & 25 & $1 \% \mathrm{NaCl}$ \\
$\begin{array}{l}\text { American Cynamid } \\
\text { No. } 930\end{array}$ & $5 \times 10^{6}$ & 25 & deionized water \\
\hline
\end{tabular}




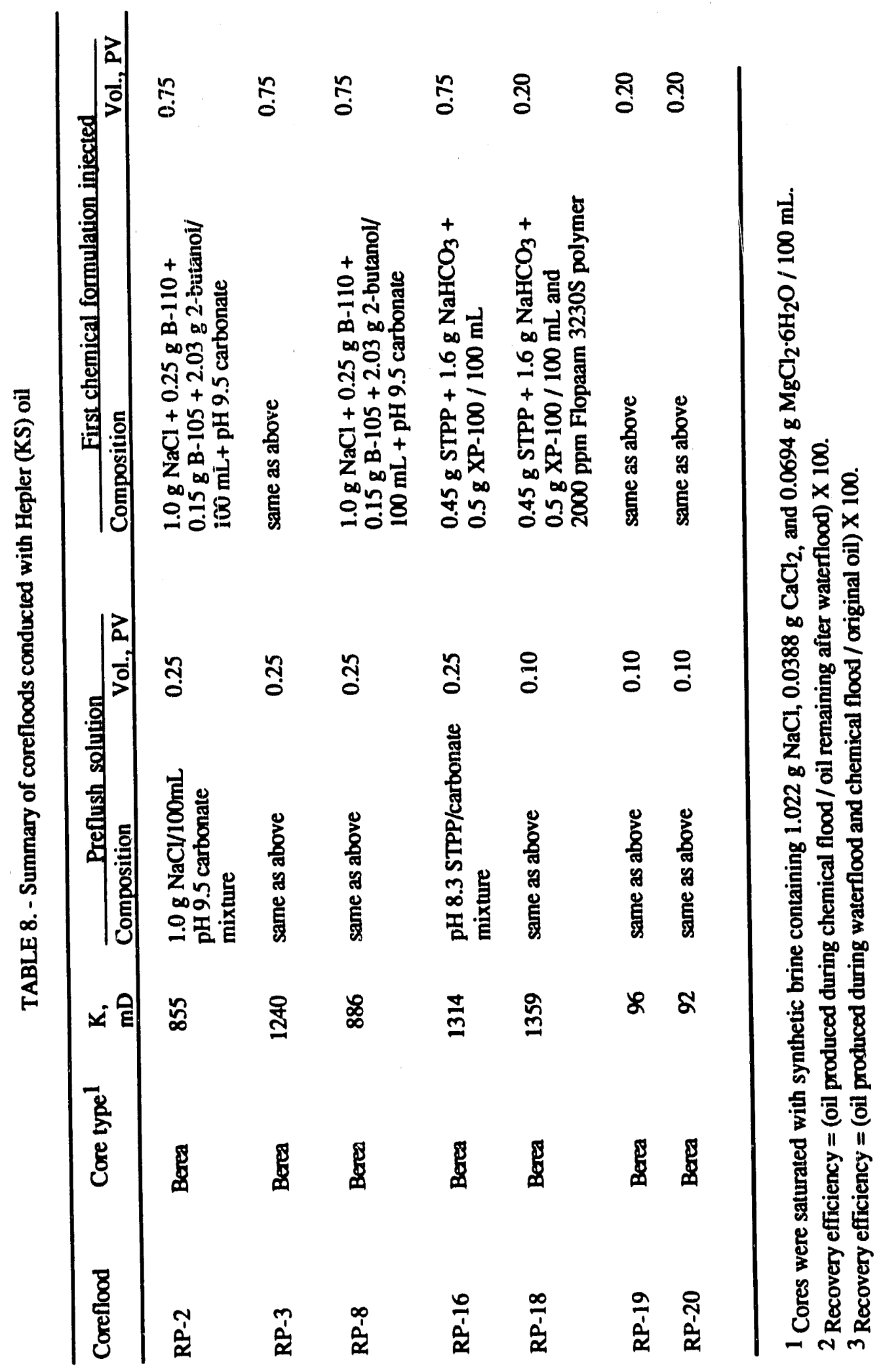




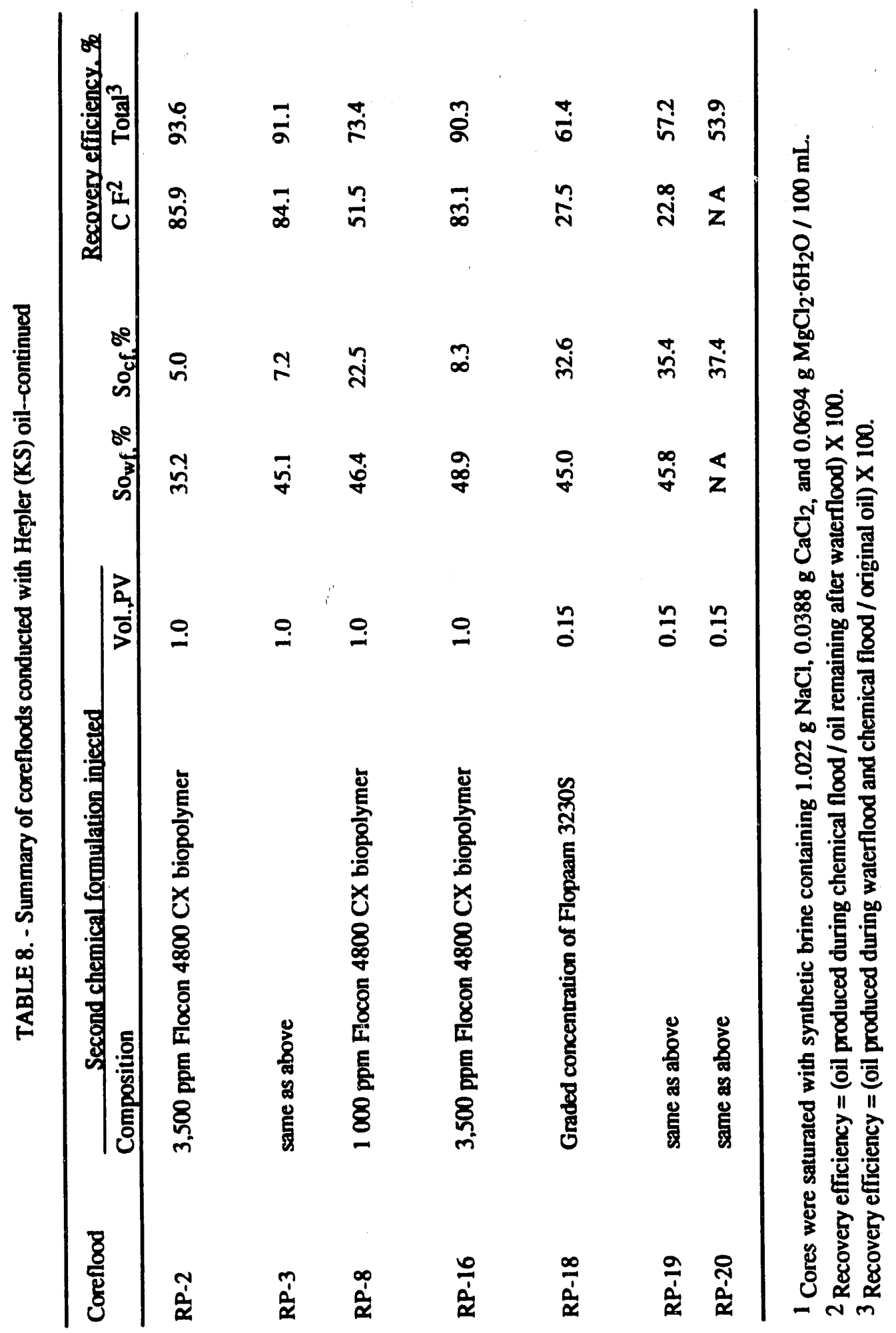


TABLE 9. - Alkali consumption with Hepler field core

\begin{tabular}{ccc}
\hline Alkali & \multicolumn{2}{c}{ Consumption meqake } \\
\cline { 2 - 3 } 3 Days & 1 & 31 Days \\
\hline $\begin{array}{l}0.19 \mathrm{~N} \mathrm{NaHCO}_{3} \\
0.095 \mathrm{~N} \mathrm{NaHCO}_{3} \\
+0.095 \mathrm{~N} \mathrm{Na}_{2} \mathrm{CO}_{3}\end{array}$ & 3 & 6 \\
$0.19 \mathrm{~N} \mathrm{Na}_{2} \mathrm{CO}_{3}$ & 9 & 10 \\
$0.19 \mathrm{~N} \mathrm{NaOH}^{2}$ & 8 & 27 \\
\hline
\end{tabular}

TABLE 10. - Surfactant retention

Surfactant System

Type of test

Liquid/solid

Surfactant loss, ratio meq/kg

$0.15 \%$ B-105, 0.25\% B-110, $1 \% \mathrm{NaCl}$, and $\mathrm{pH} 9.5$ carbonate mixture in deionized water

static (batch) test with crushed Hepler field core, 1 week at $23^{\circ} \mathrm{C}$

coreflood RP-2

coreflood RP-11

coreflood RP-16 coreflood RP-18 coreflood RP-19
2

$8 \quad 6.8$

- $\quad 0.52$

-
0.35

$\begin{array}{ll}- & 0.44\end{array}$

$\begin{array}{ll}- & 0.13 \\ - & 0.15\end{array}$

$1.6 \% \mathrm{NaHCO}_{3}$ in supply well water, $\mathrm{pH} 8.3$ 


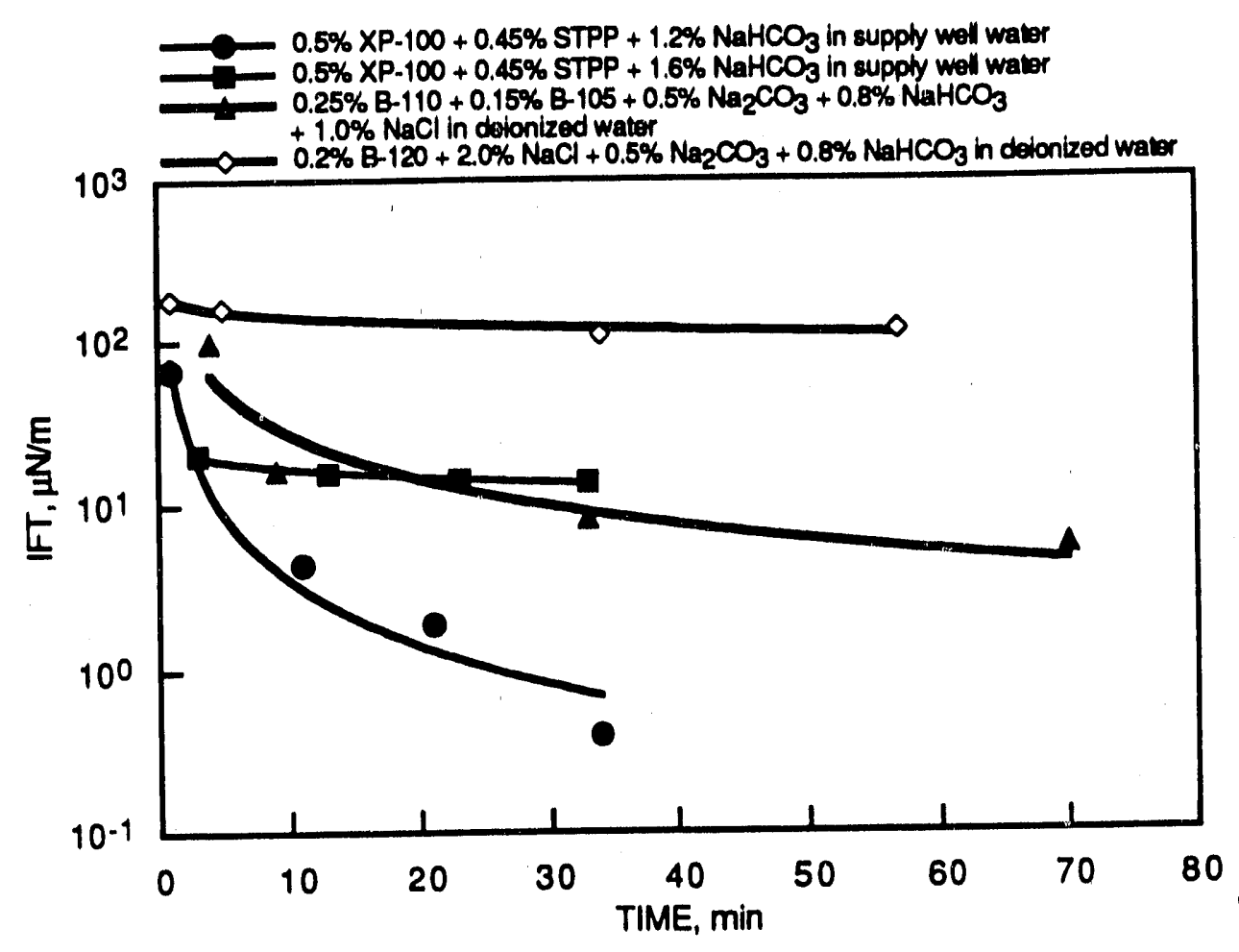

FIGURE 1. - Interfacial tension between Hepler (KS) oil and optimized chemical formulations, $23^{\circ} \mathrm{C}$.

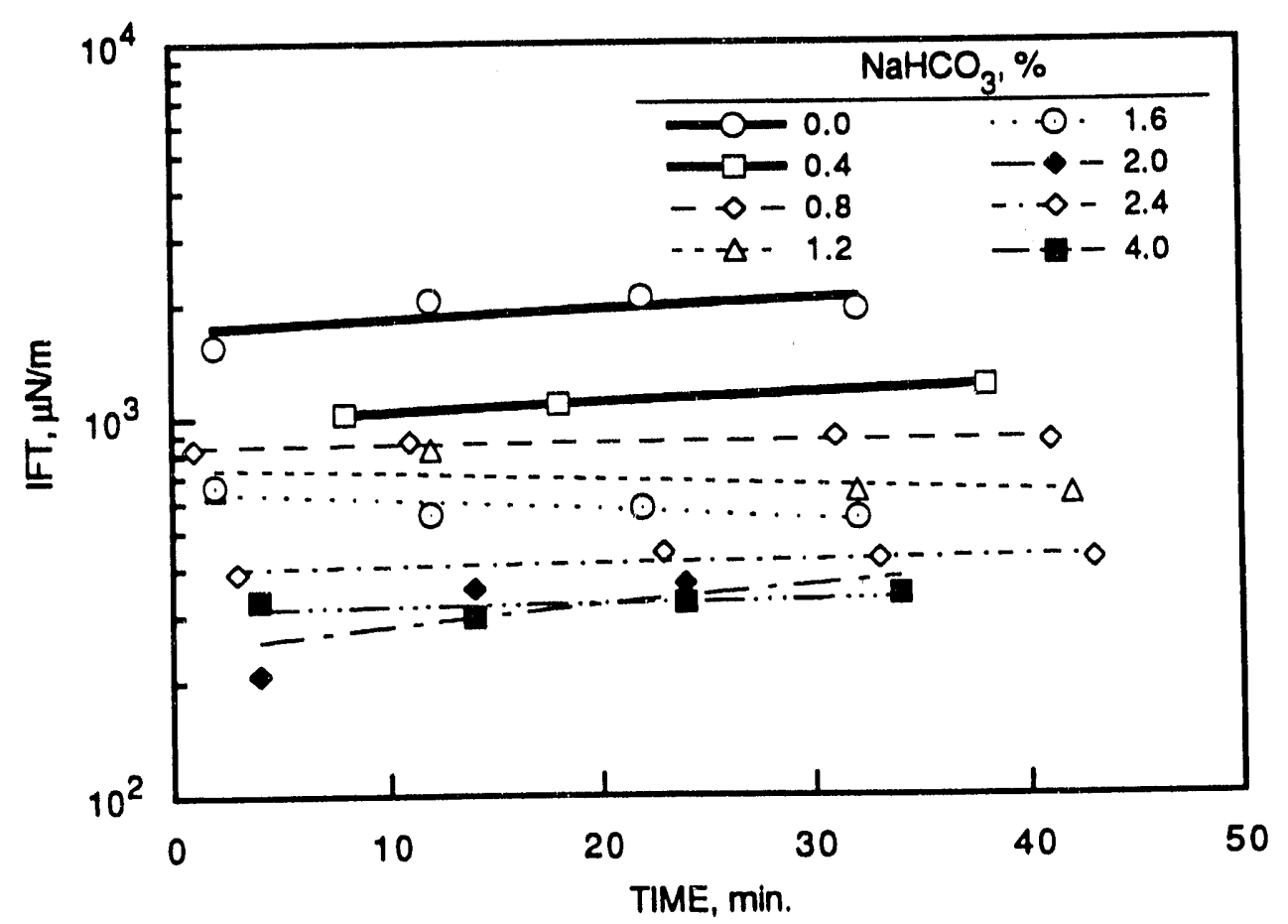

FIGURE 2. - Interfacial tension between Hepler (KS) oil and a mixture containing $0.5 \% \mathrm{~T}-33$, $0.45 \%$ STPP, and sodium bicarbonate in water from supply we' $23^{\circ} \mathrm{C}$. 


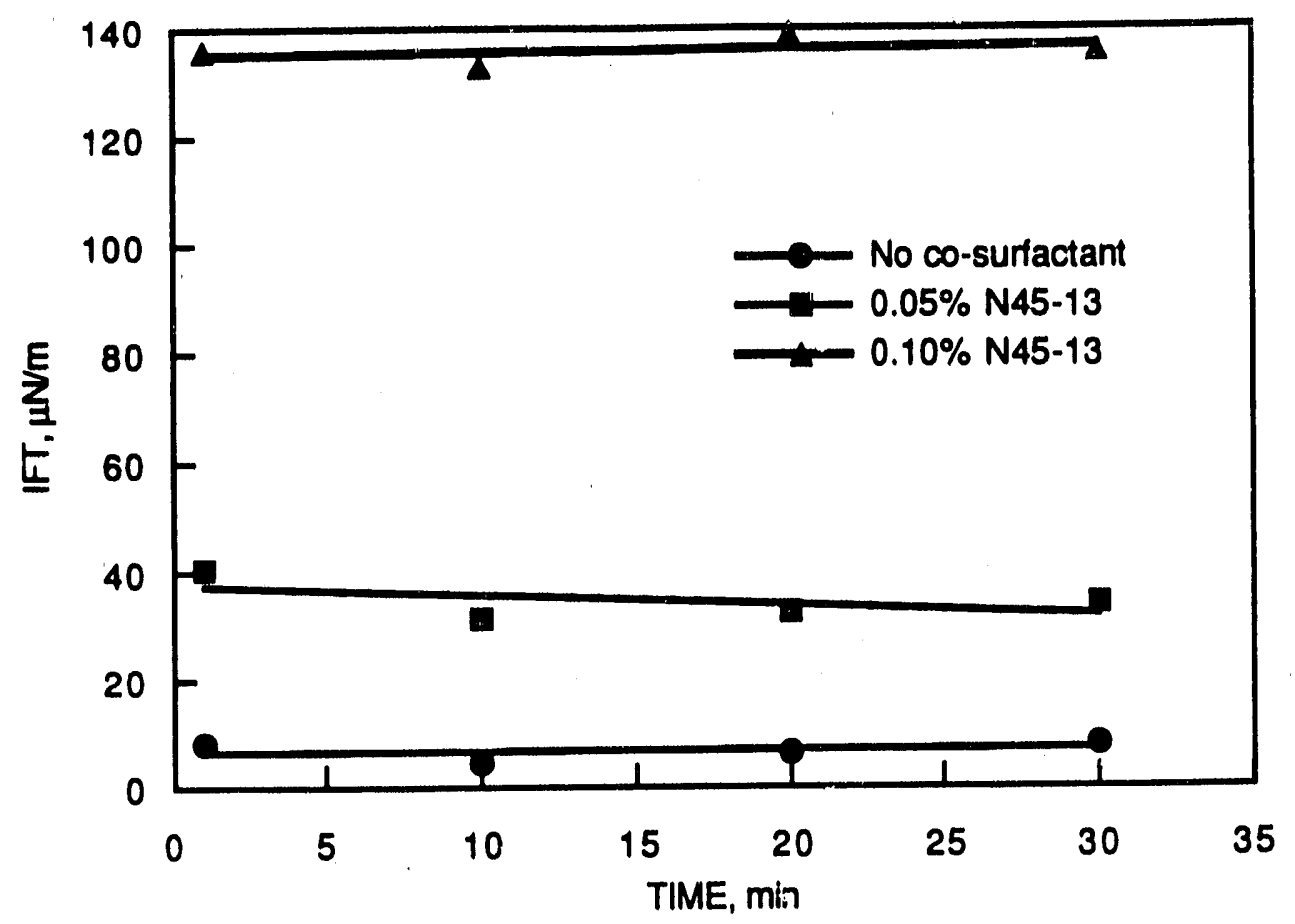

FIGURE 3. - Interfacial tension between Hepler (KS) oil and a mixture containing 0.5\% XP-100, $2.0 \%$ STPP, and Neodol $45-13$ in water from supply well, $23^{\circ} \mathrm{C}$.

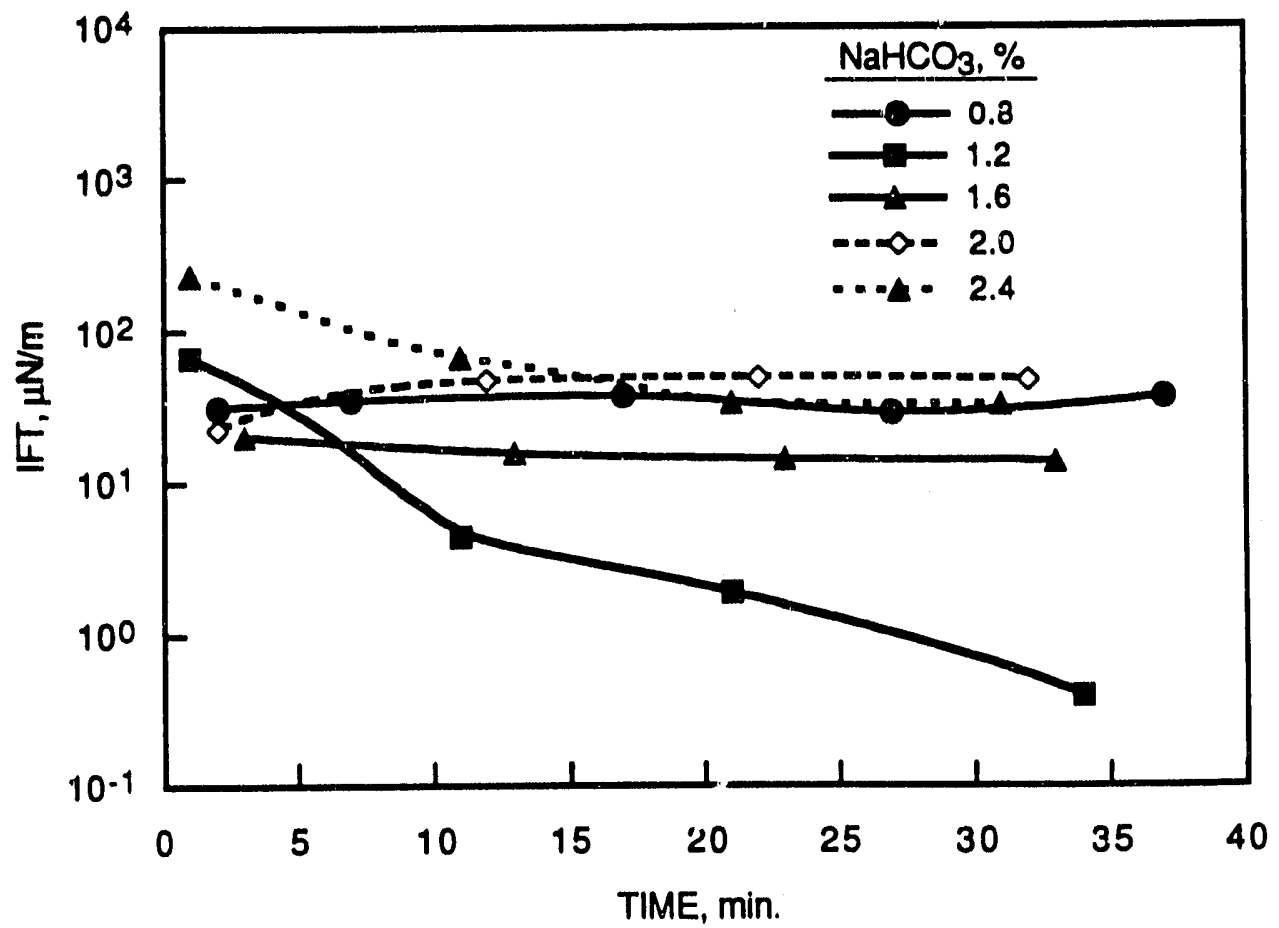

FIGURE 4. - Interfacial tension between Hepler (KS) oil and a mixture containing 0.5\% XP-100, $0.45 \%$ STPP, and sodium bicarbonate in water from supply well, $23^{\circ} \mathrm{C}$. 


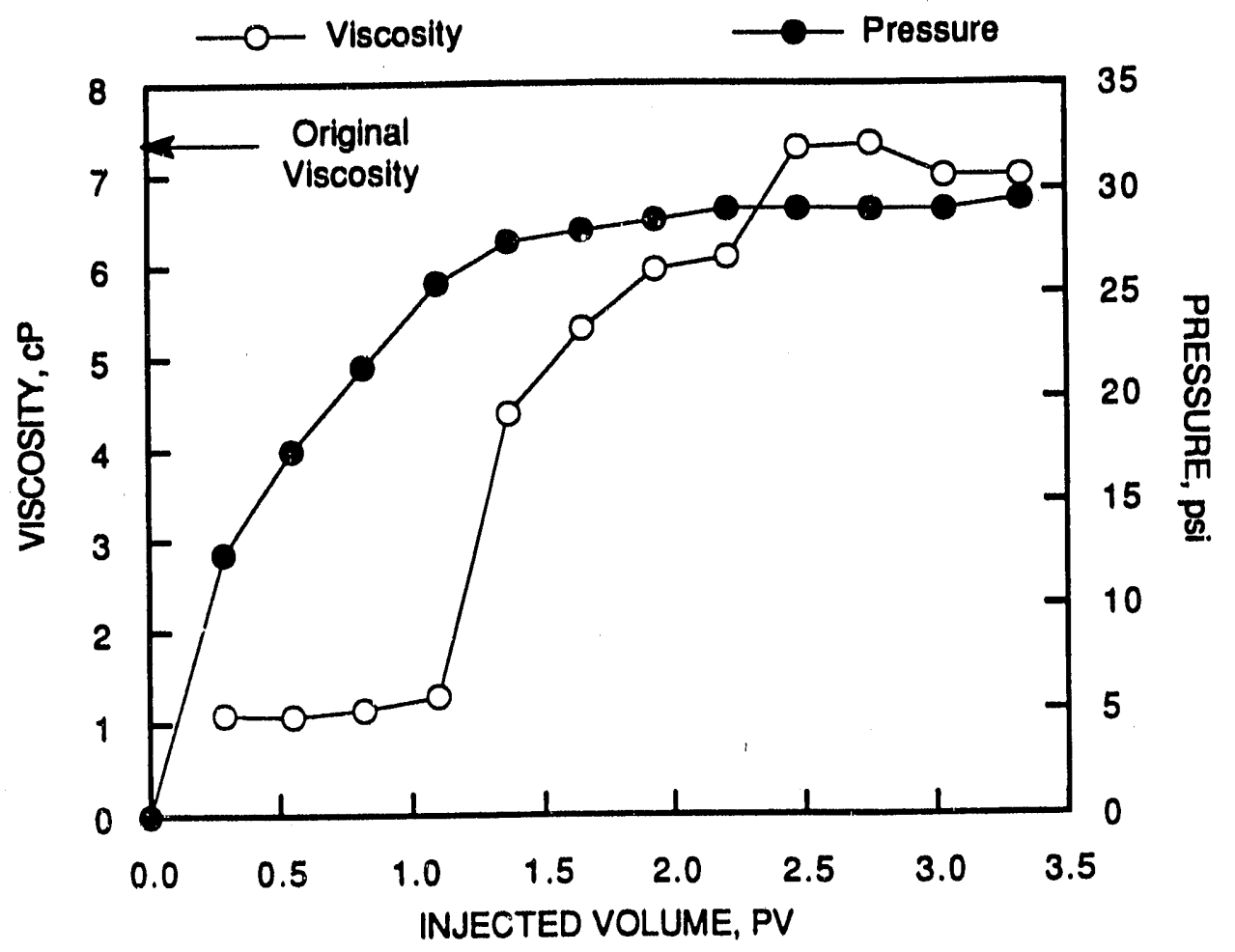

FIGURE 5. - Pfizer Flopaam 3230E polymer injectivity test.

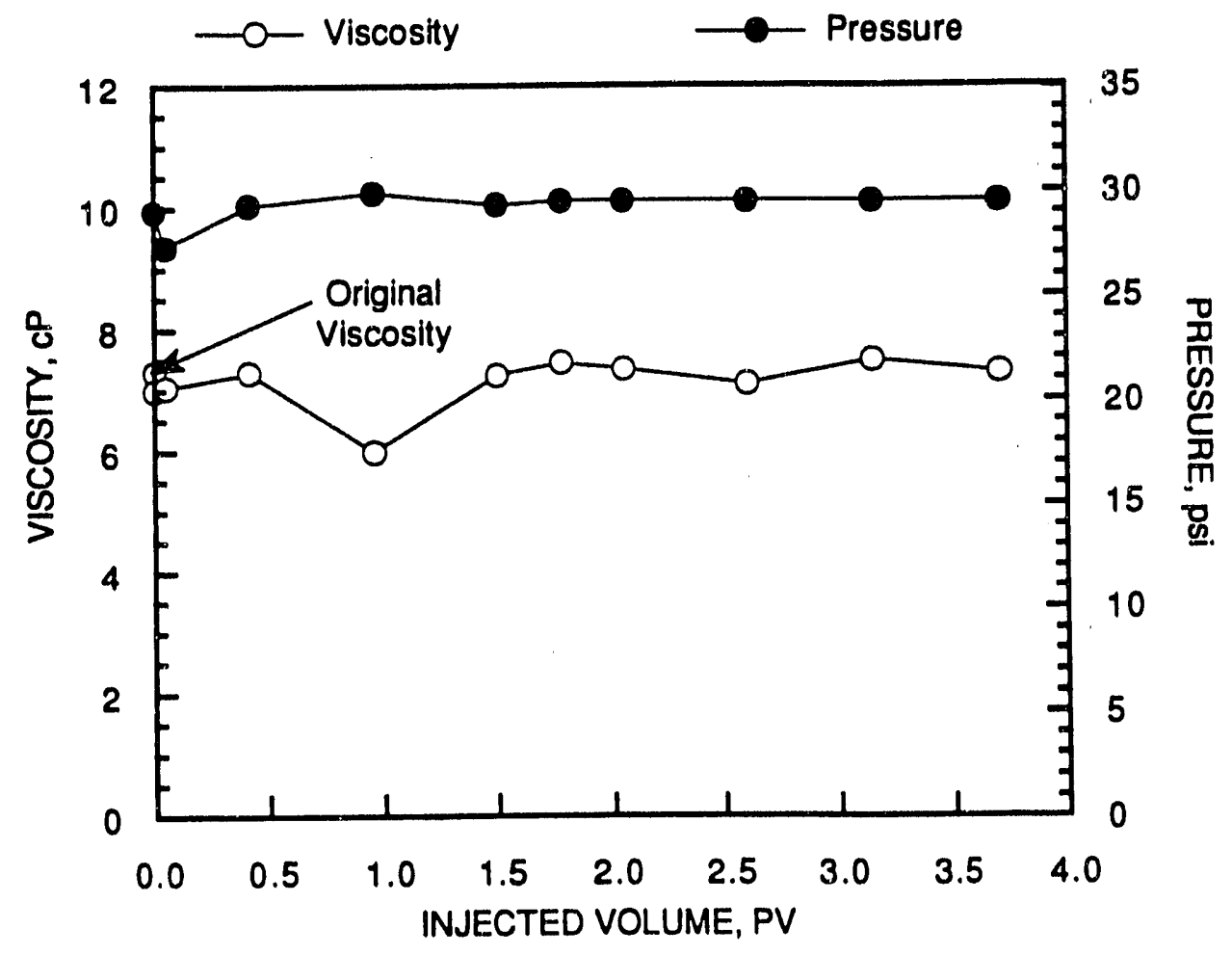

FIGURE 6. - American Cynamid 920 polymer injectivity test. 


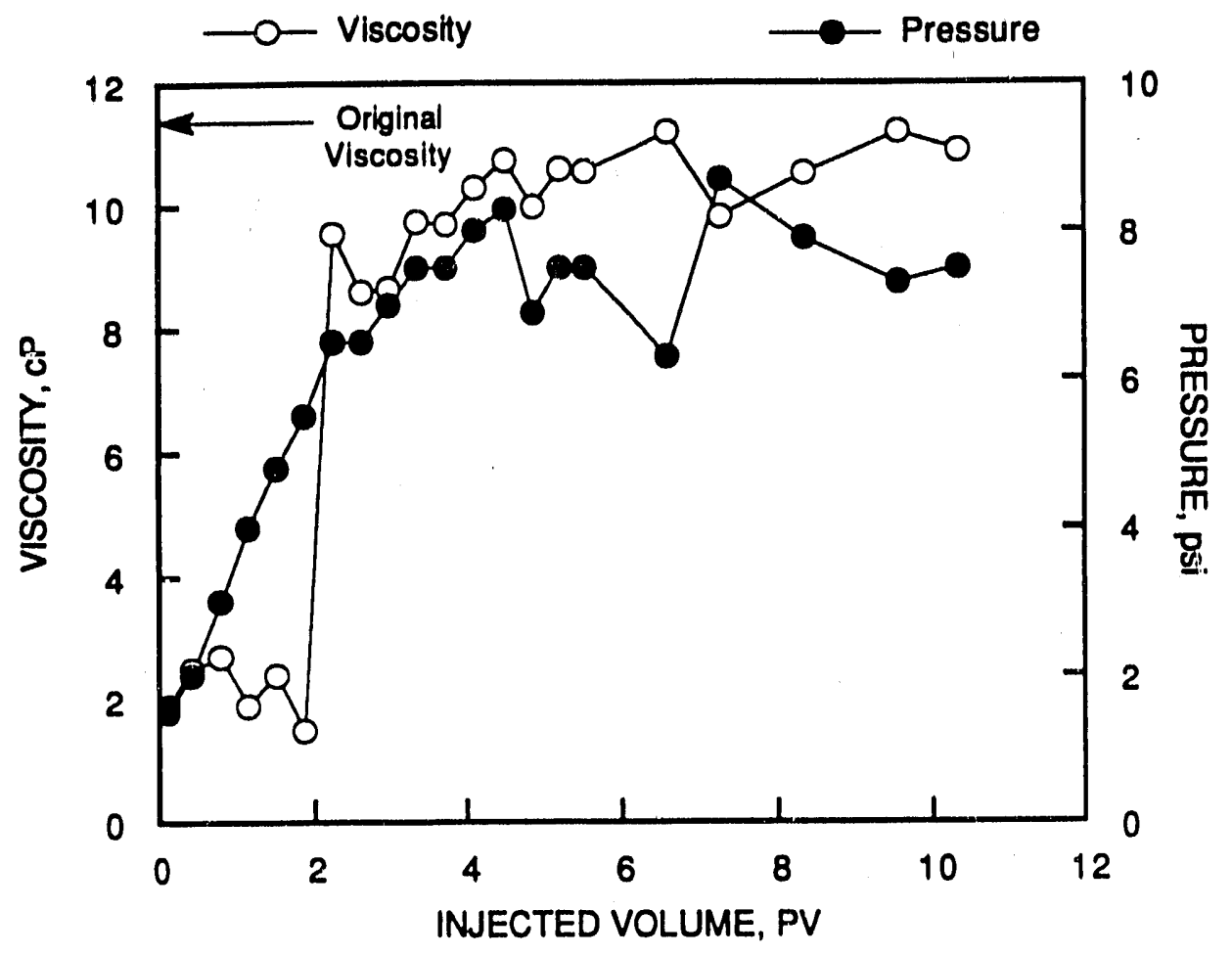

FIGURE 7. - Pfizer Flocon $4800 C X$ polymer injectivity test.

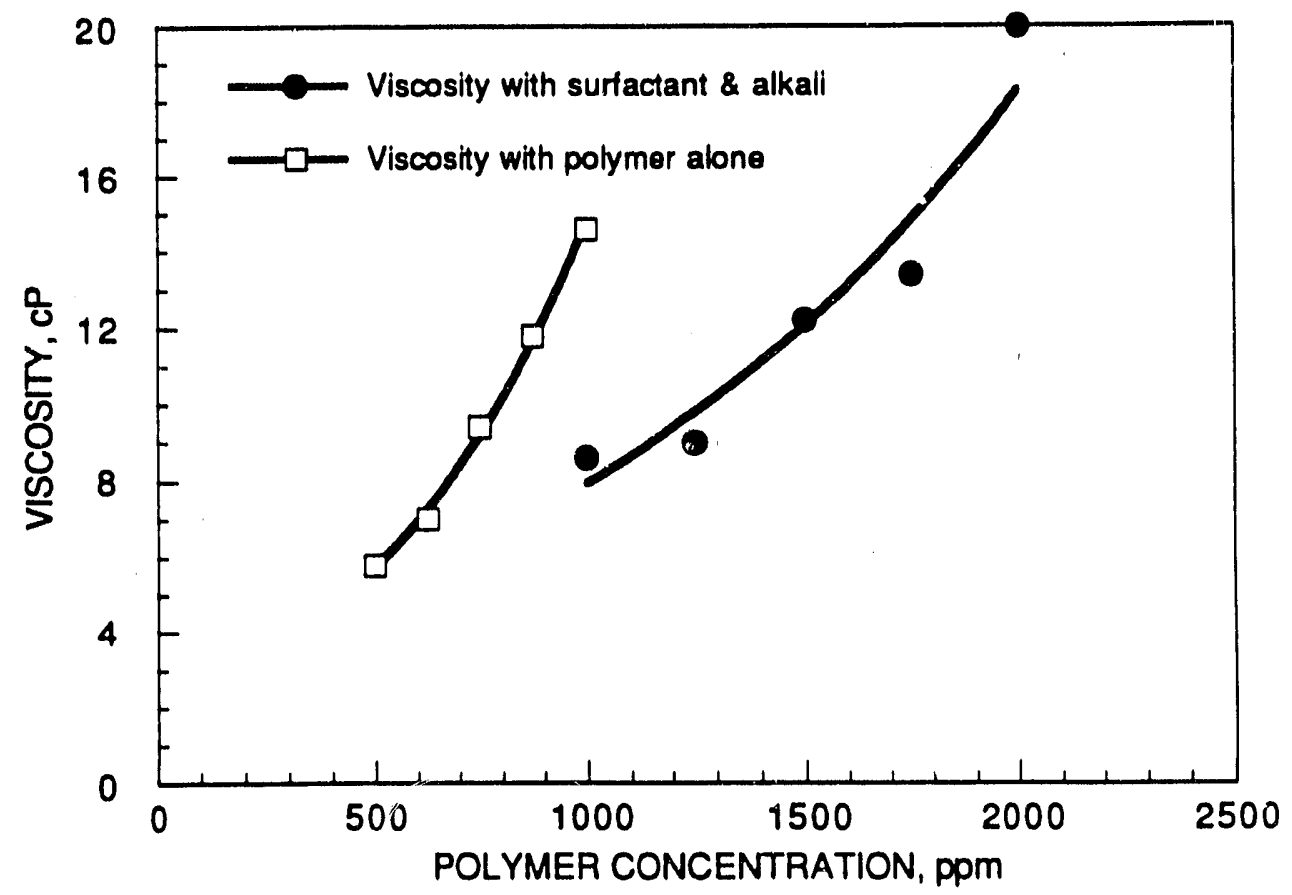

FIGURE 8. - Viscosity of Flopaam 3230 S polymer in supply well water, $11.5 \mathrm{sec}^{-1}, 23^{\circ} \mathrm{C}$. 


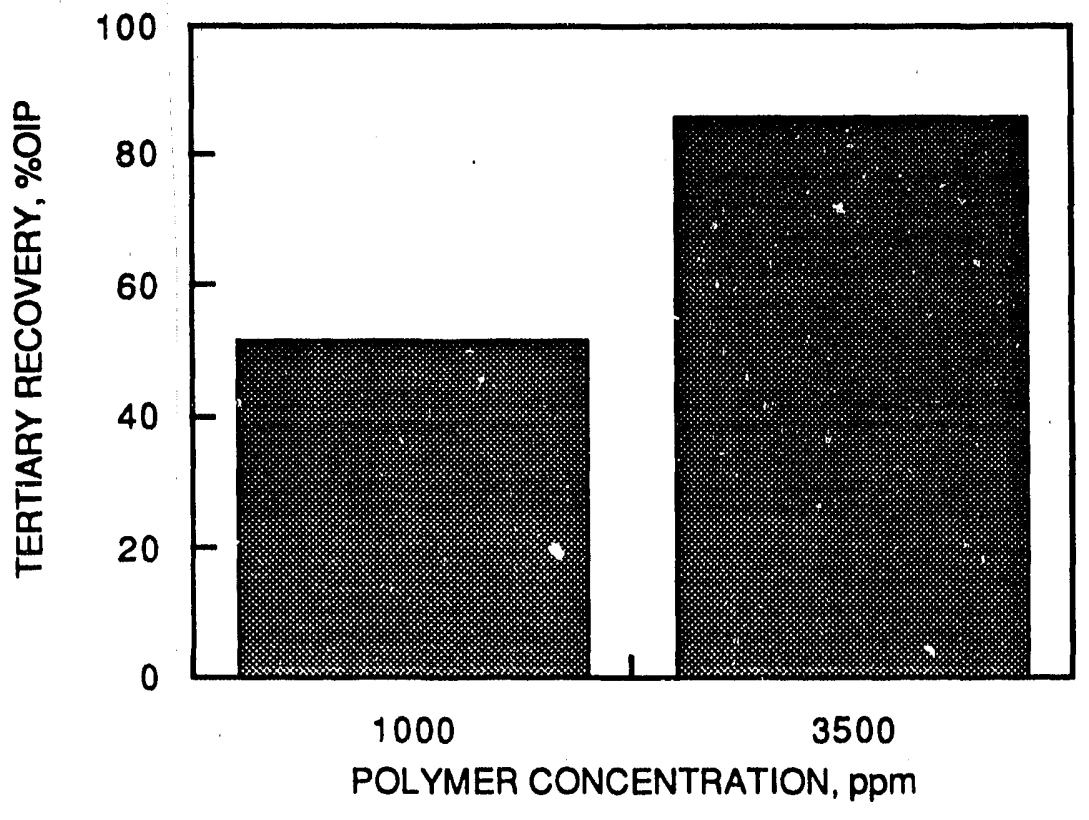

FIGURE 9. - Effect of polymer concentration on tertiary oil recovery. 


\section{APPENDIX A. COREFLOOD EFFLUENT ANALYSES}

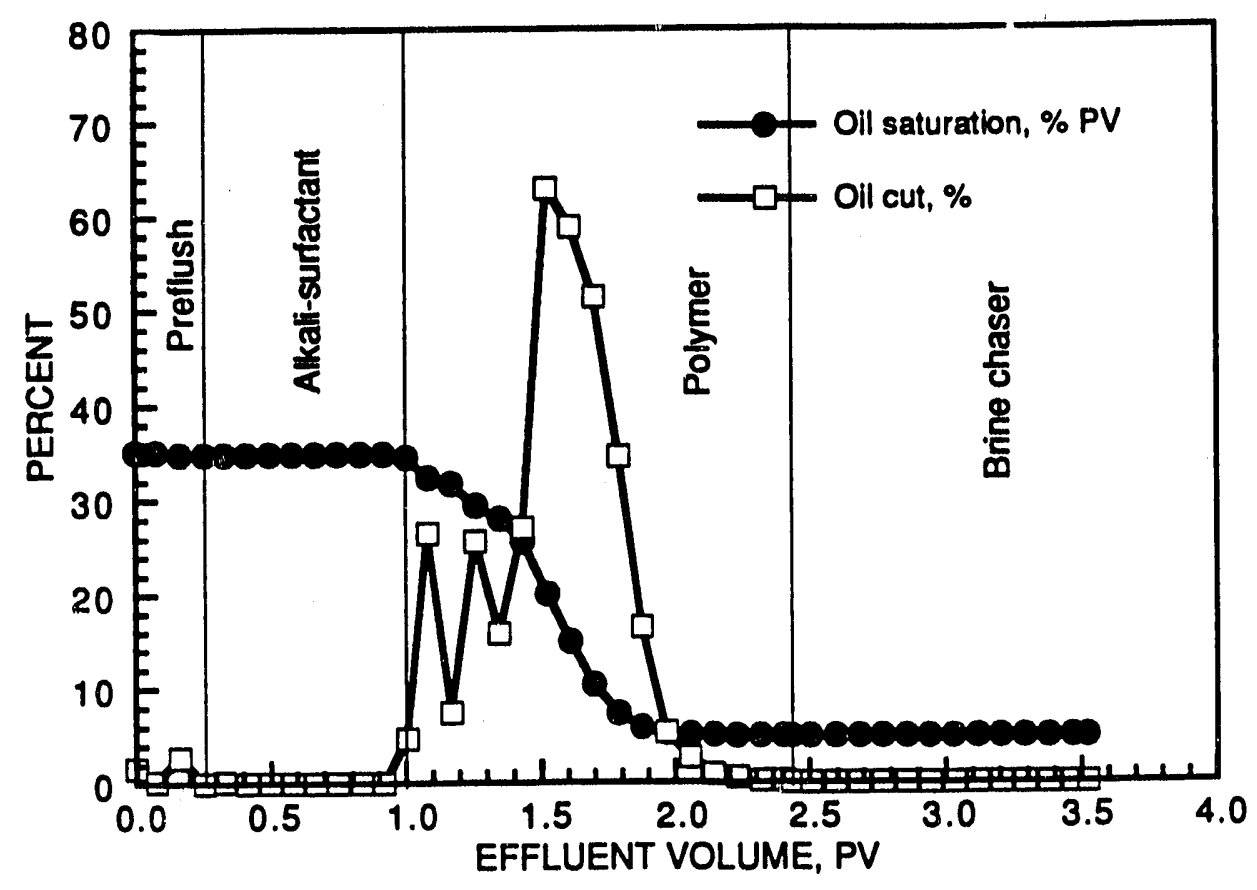

FIGURE A1. - Coreflood RP-2 oil saturation and effluent oil cut.

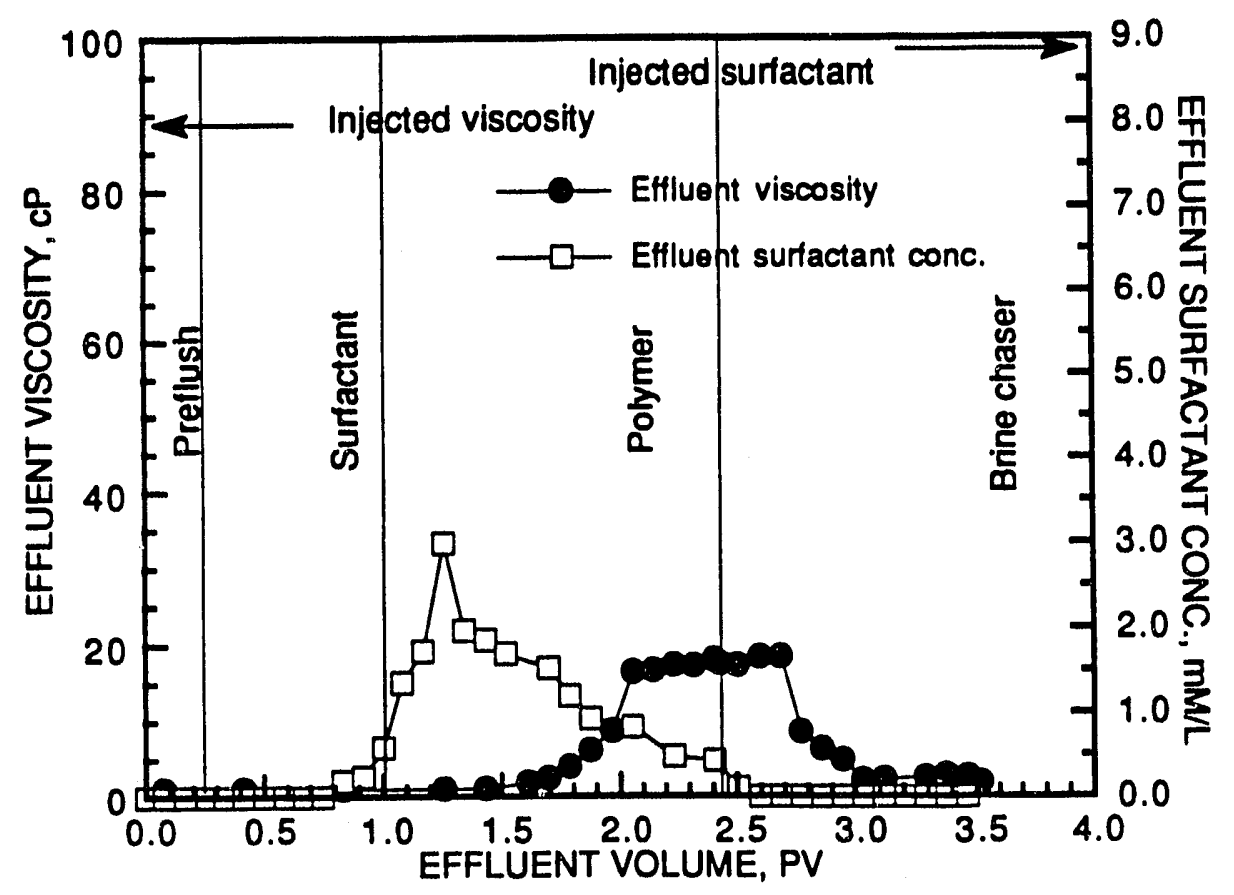

FIGURE A2. - Coreflood RP-2 effluent viscosity and surfactant analysis. 


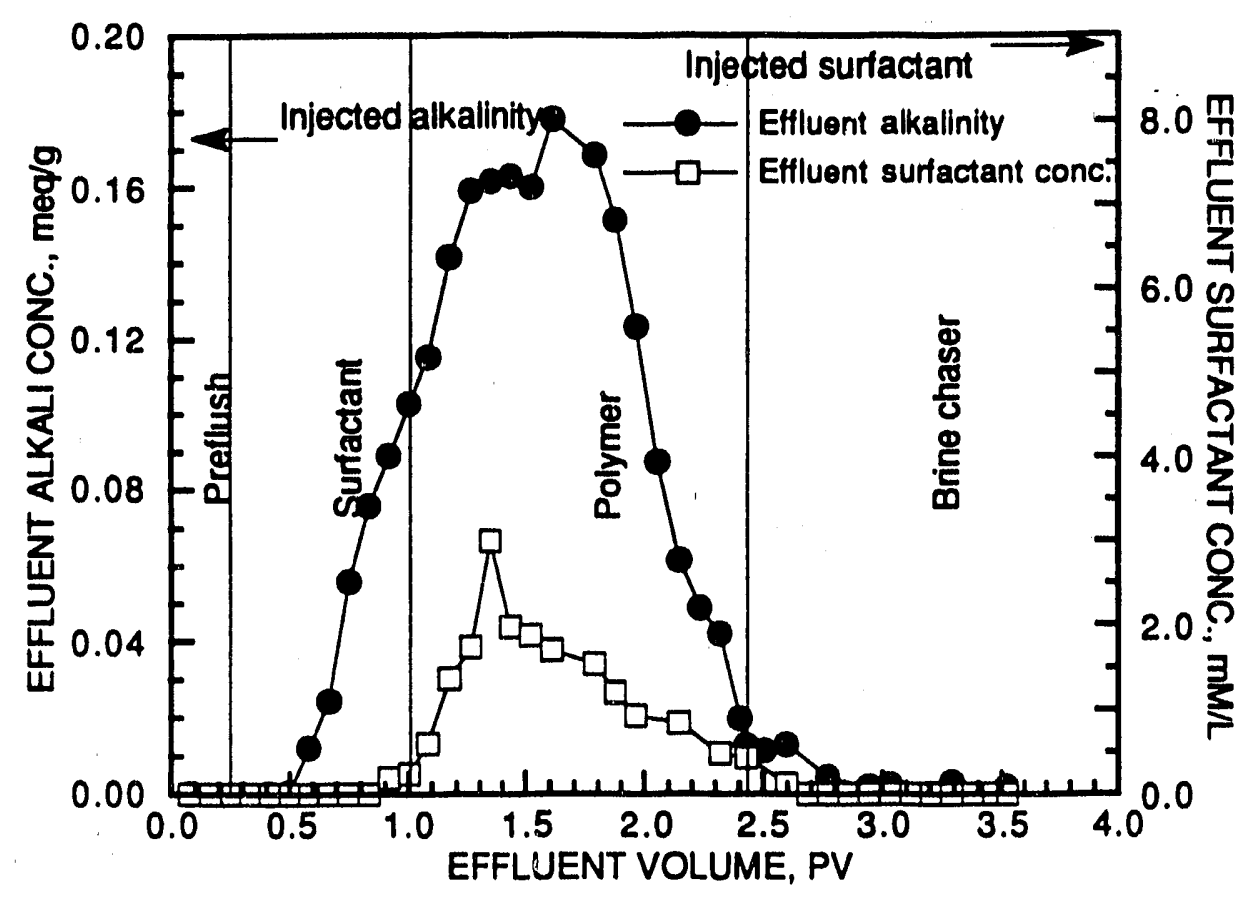

FIGURE A3. - Coreflood RP-2 effluent alkalinity and surfactant analysis.

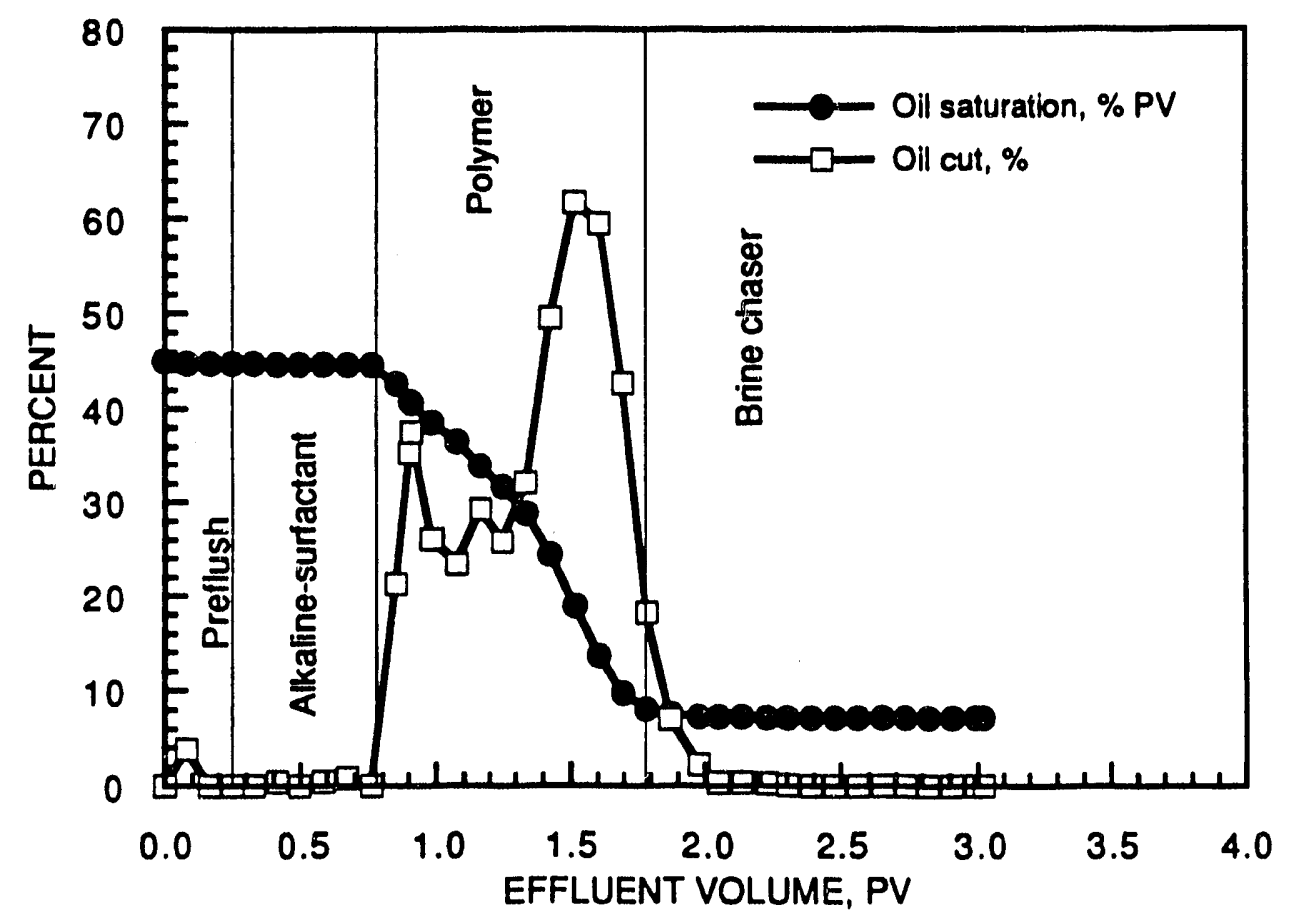

FIGURE A4. - Coreflood RP-3 oil saturation and effluent oil cut. 


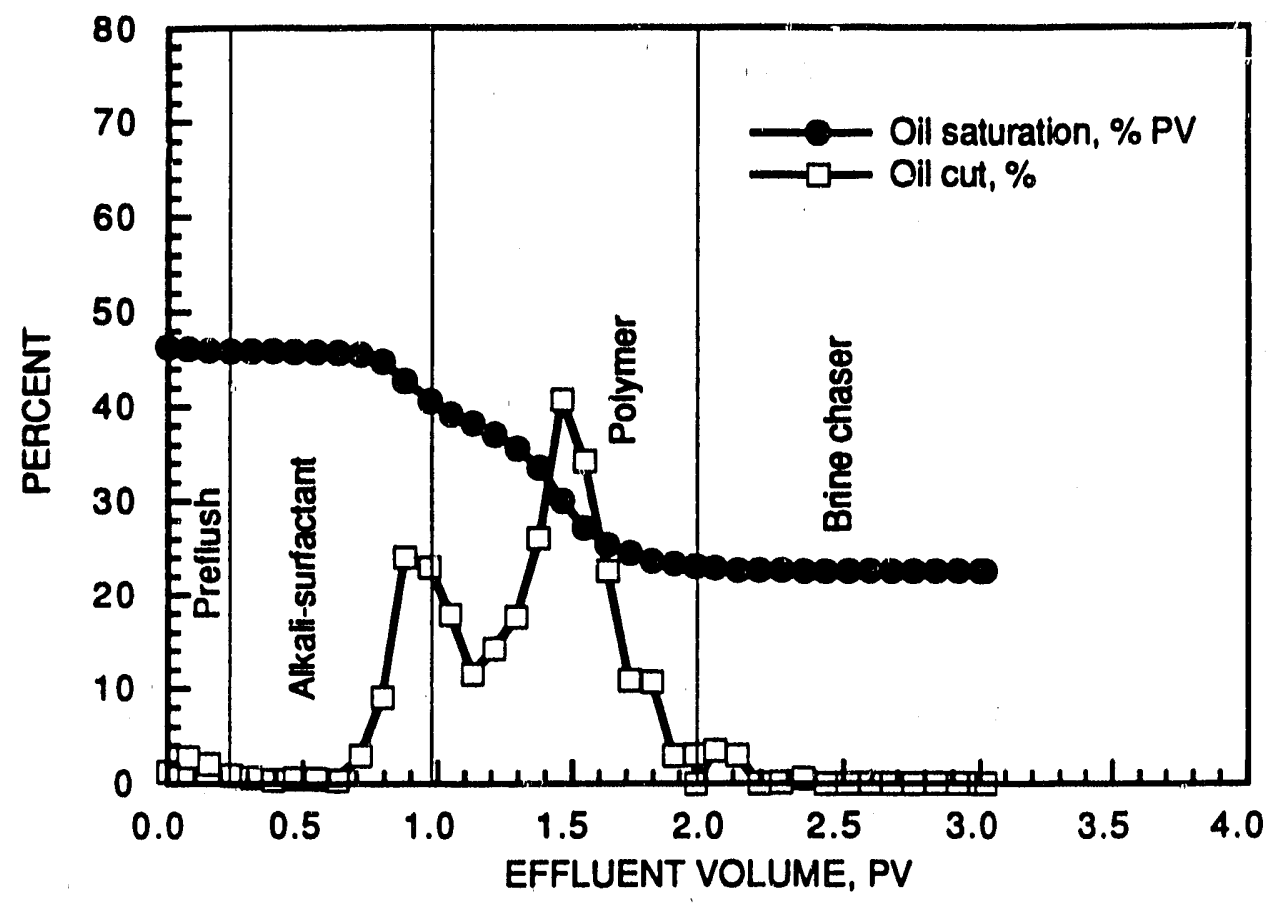

FIGURE A5. - Coreflood RP-8 oil saturation and effluent oil cut.

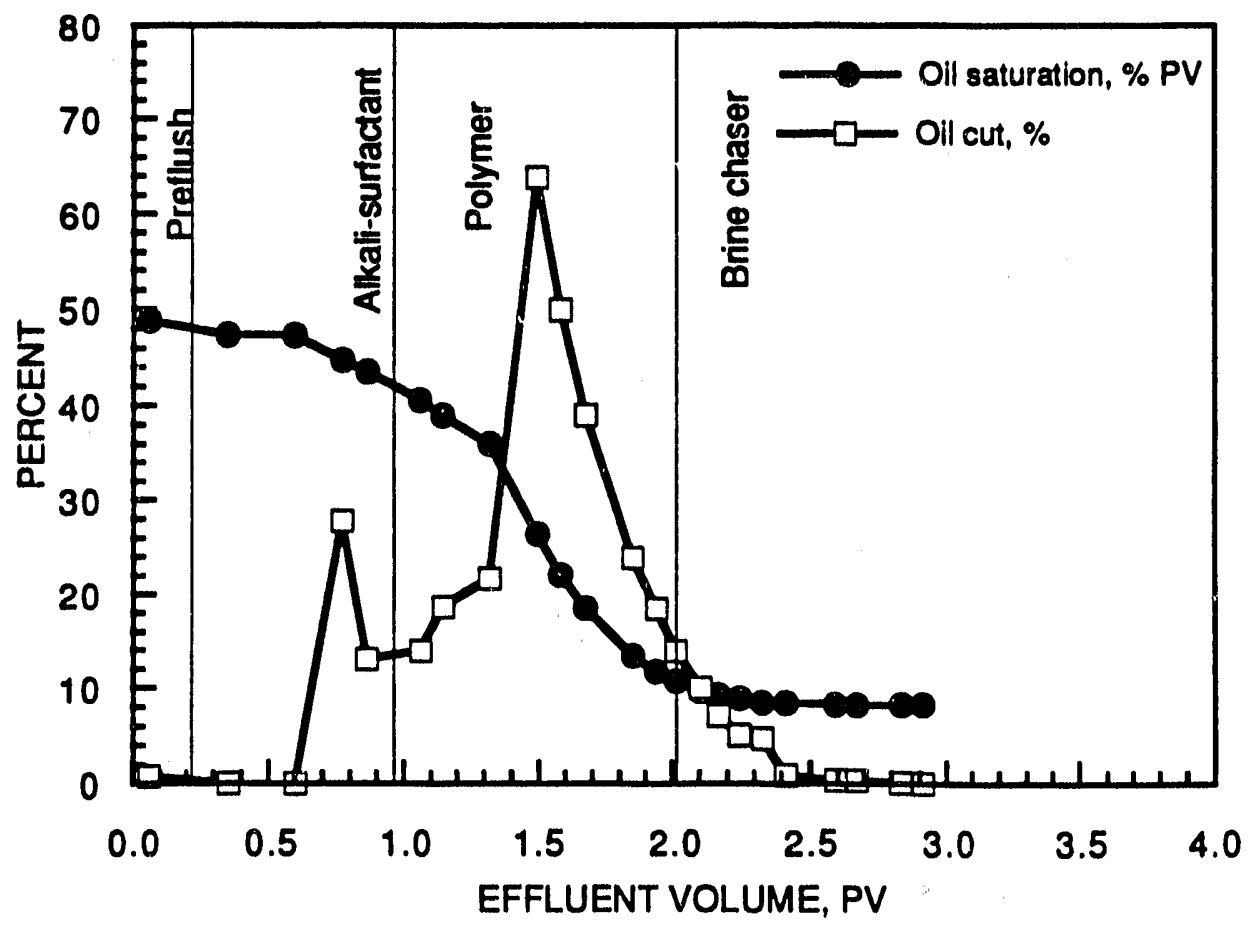

FIGURE A6. - Coreflood RP-16 oil saturation and effluent oil cut. 


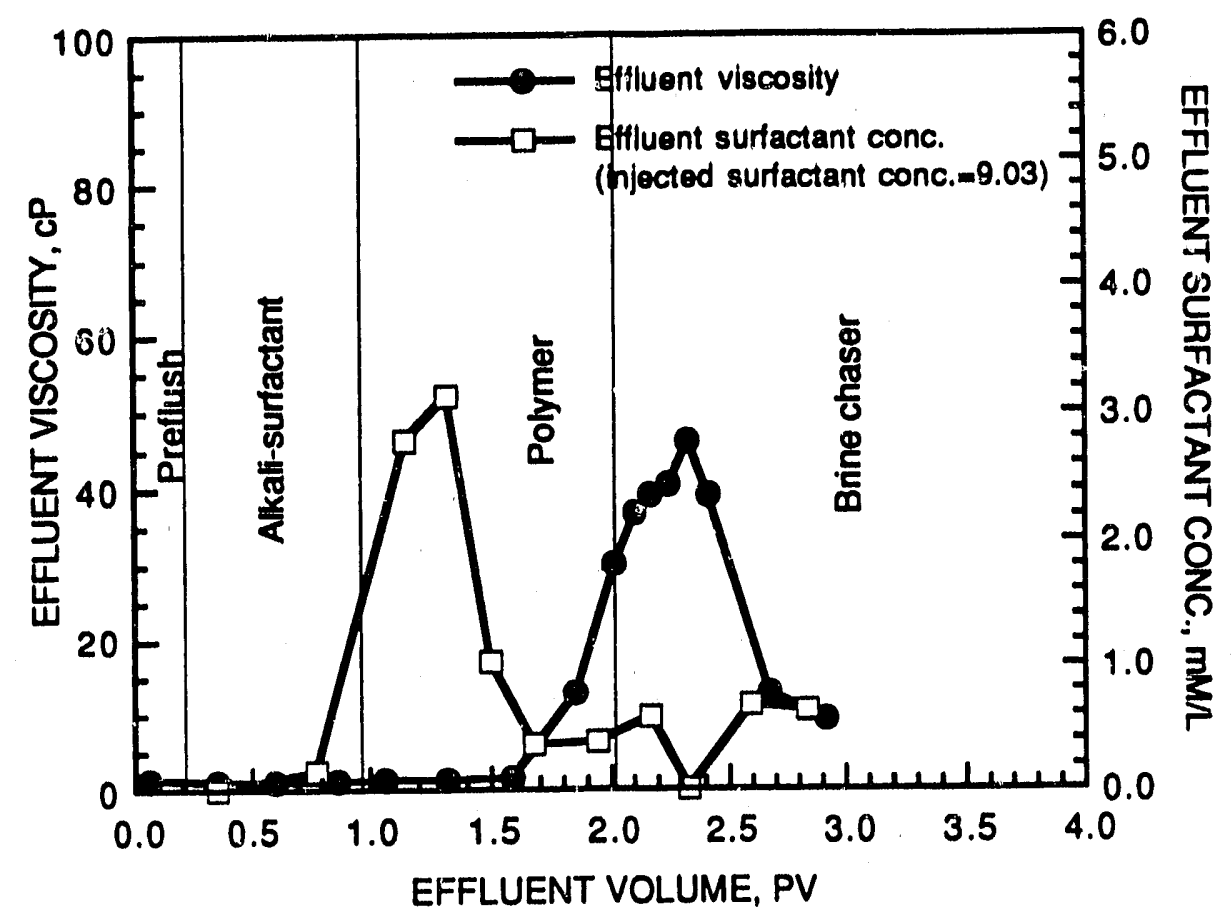

FIGURE A7. - Coreflood KP-16 effluent viscosity and surfactant analysis.

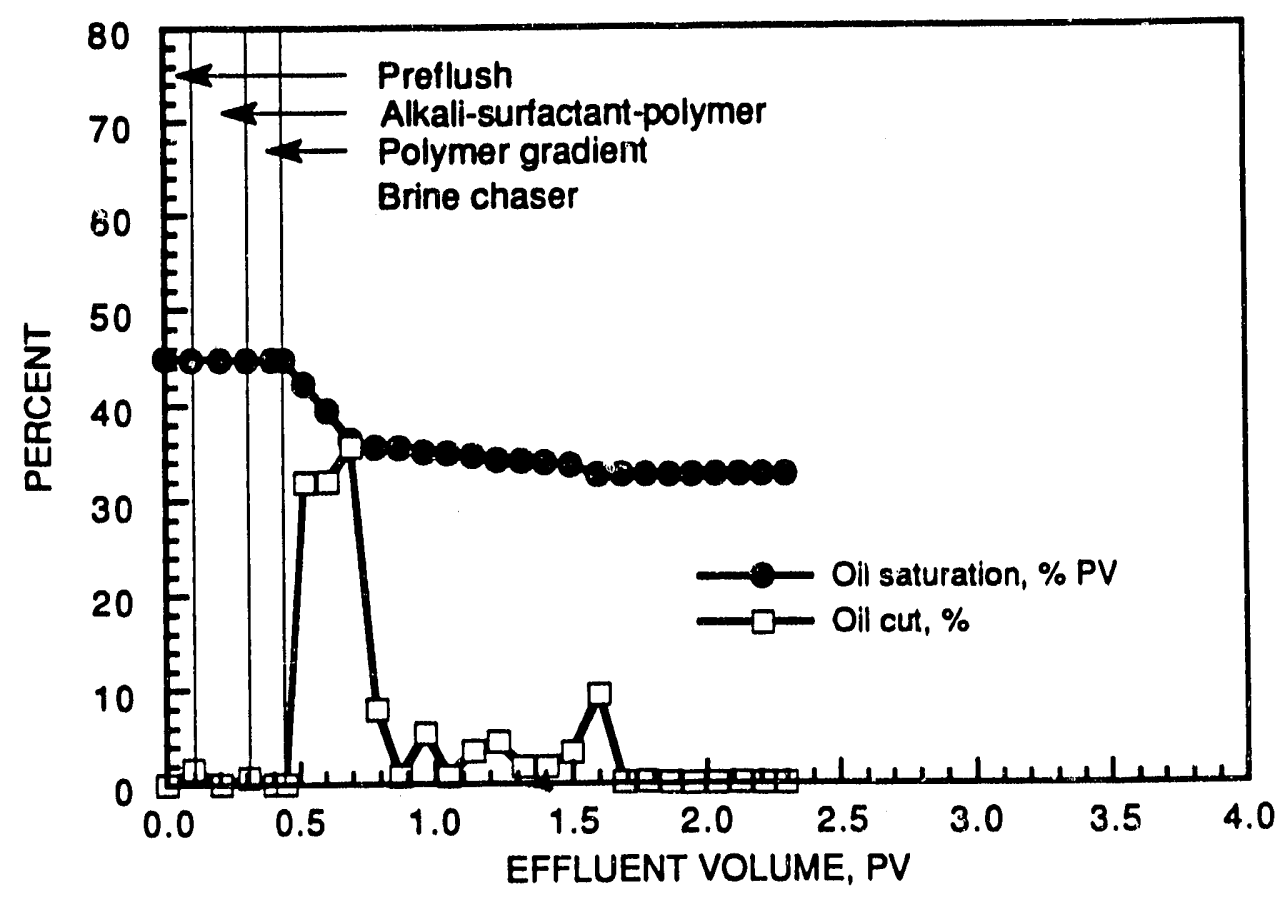

FIGURE A8. - Coreflood RP-18 oil saturation and effluent oil cut. 


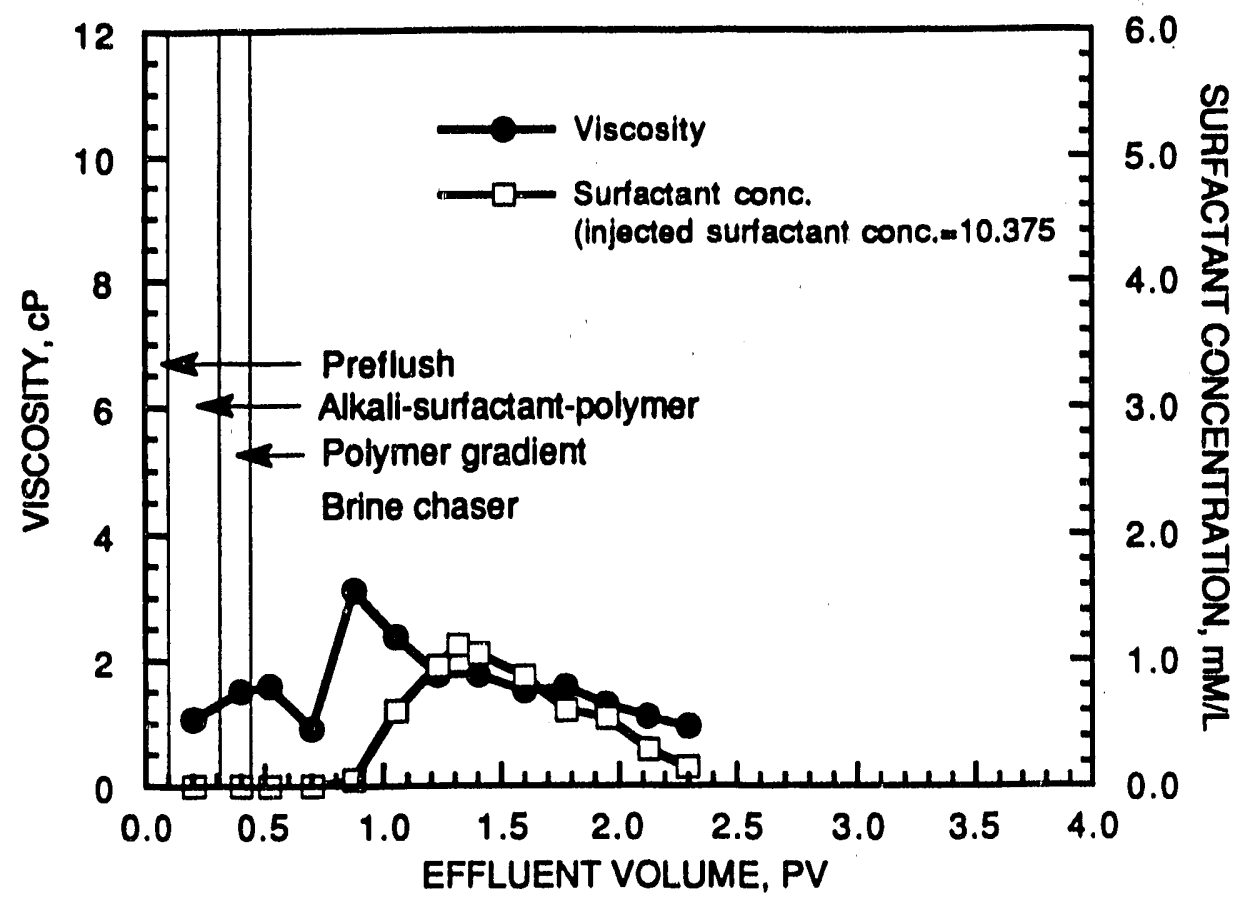

FIGURE A9. - Coreflood RP-18 effluent viscosity and surfactant analysis.

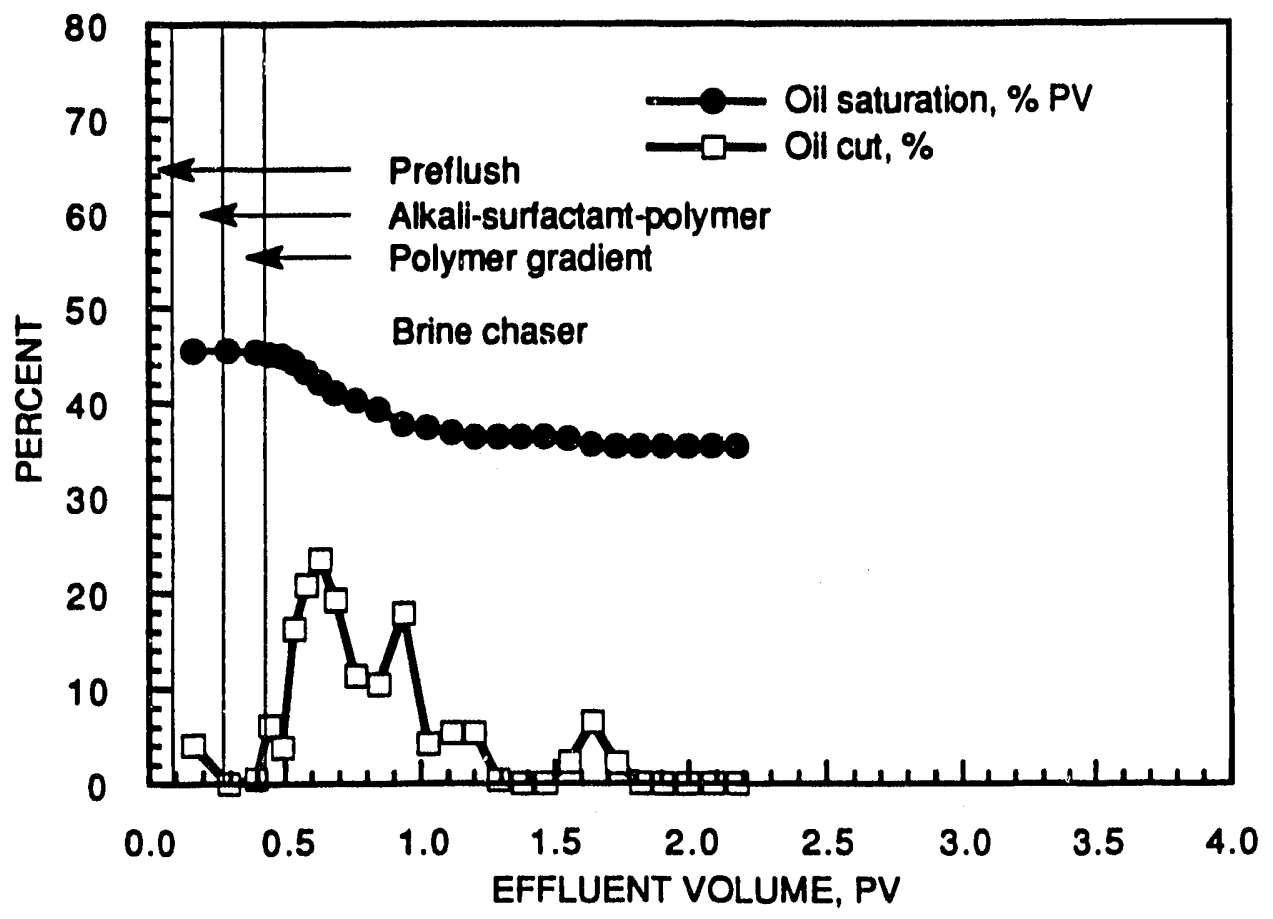

FIGURE A10. - Coreflood RP-19 oil saturation and effluent oil cut. 


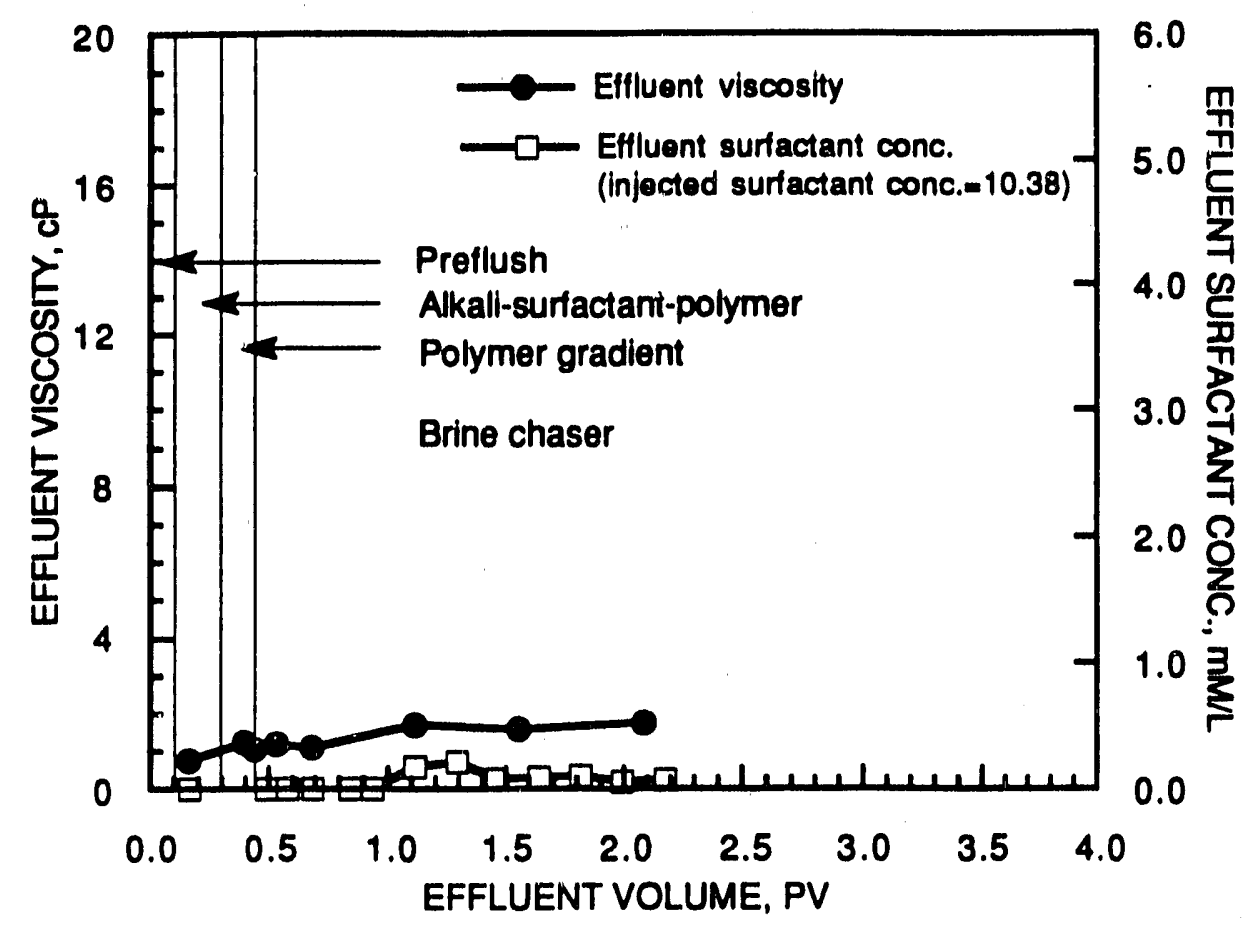

FIGURE A11. - Coreflood RP-19 effluent viscosity and surfactant analysis.

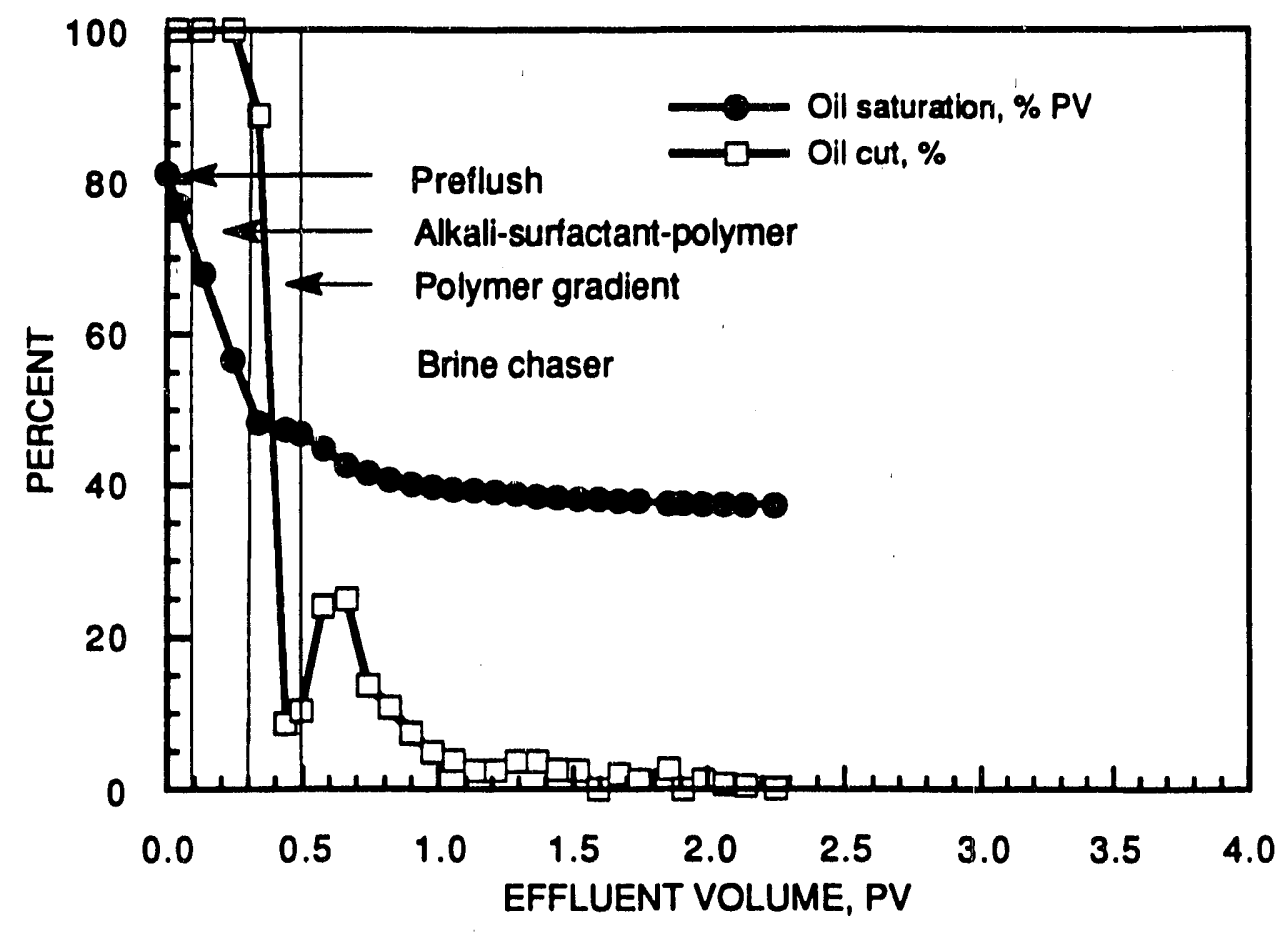

FIGURE A12. - Corefloud RP-20 oil saturation and effluent oil cut. 

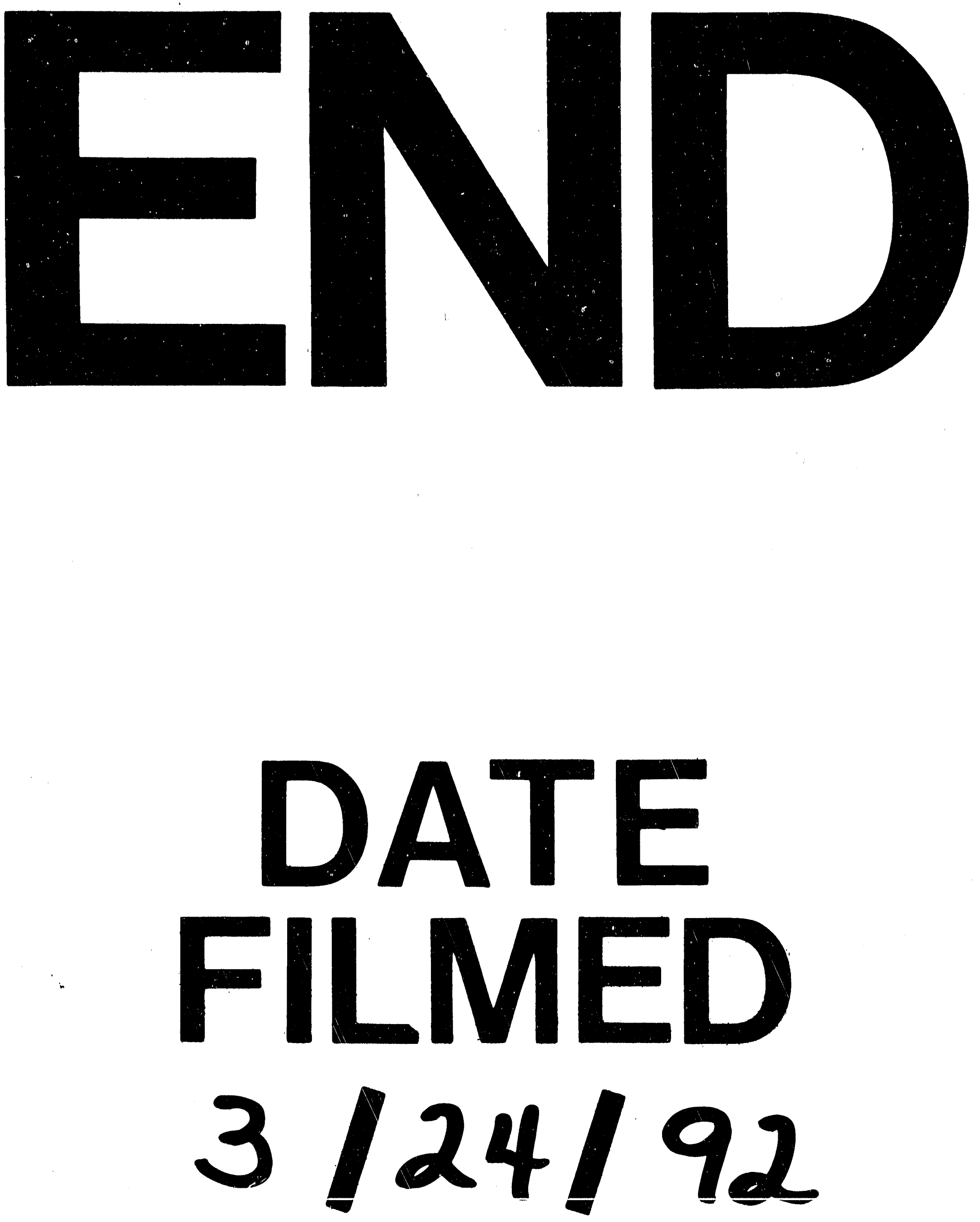
